\title{
Monastic archaeology and national identity: the Scottish monastic experience
}

\author{
Book or Report Section
}

Published Version

Creative Commons: Attribution-Noncommercial-No Derivative Works 4.0

Open access

Gilchrist, R. (2020) Monastic archaeology and national identity: the Scottish monastic experience. In: Gilchrist, R. Sacred Heritage: Monastic Archaeology, Identities, Beliefs. Cambridge University Press, Cambridge, pp. 37-70. ISBN 9781108678087 doi:

https://doi.org/10.1017/9781108678087.003 Available at https://centaur.reading.ac.uk/88521/

It is advisable to refer to the publisher's version if you intend to cite from the work. See Guidance on citing.

To link to this article DOI: http://dx.doi.org/10.1017/9781108678087.003

Publisher: Cambridge University Press

Publisher statement: An online version of this work is published at doi.org/10.1017/9781108678087 under a Creative Commons Open Access license CC-BY-NC-ND 4.0 which permits re-use, distribution and reproduction in any medium for non-commercial purposes providing appropriate credit to the original work is given. You may not distribute derivative works without permission. To view a copy of this license, visit https://creativecommons.org/licenses/by-nc$\mathrm{nd} / 4.0$. All versions of this work may contain content reproduced under license from third parties. Permission to reproduce this third-party content must be obtained from these third-parties directly.

All outputs in CentAUR are protected by Intellectual Property Rights law, including copyright law. Copyright and IPR is retained by the creators or other 
copyright holders. Terms and conditions for use of this material are defined in the End User Agreement.

\section{www.reading.ac.uk/centaur}

\section{CentAUR}

Central Archive at the University of Reading

Reading's research outputs online 


\section{TWO}

\section{MONASTIC ARCHAEOLOGY AND NATIONAL IDENTITY: THE SCOTTISH MONASTIC EXPERIENCE}

\section{INTRODUCTION: REGIONAL RESEARCH TRADITIONS}

This chapter considers archaeological approaches to the study of later medieval monasticism in Scotland, providing a case study through which to explore the regional character of monasticism and the factors that influence archaeological scholarship today. It reflects on how the construction of archaeological knowledge is shaped by national identity and the contemporary social value that we place on medieval heritage. Archaeology has played a salient role in the construction of national identities across Europe over the past 200 years, through the development of institutions such as museums, universities and national heritage agencies, and the selected versions of the past that they promote to the public (Díaz-Andreu and Champion 1996). National identity is understood here to refer to an individual's sense of belonging represented through collective culture, language, politics and heritage (both tangible and intangible), shared by a group of people regardless of whether the nation is formally constituted as a state (Greenfeld and Eastwood 2009). The archaeology of national identity often focuses on religious or sacred monuments and the perpetuation of 'Golden Age' narratives, periods celebrated for their artistic or technological achievements or military and political power (see Chapter 6). The primary function of nationalistic archaeology is to bolster the pride of peoples who feel deprived of political rights by more powerful nations (Trigger I984: 360). 
The chronological focus of this chapter is on the Scottish transition to reformed monasticism in the twelfth century, when Scotland embraced reformed orders of monks, canons and nuns, such as the Cistercians and Augustinians. The end of monasticism in Scotland is discussed as a case study in Chapter 5, examining the distinctive experience of Scottish religious houses following the Reformation Parliament in I560. There was no formal dissolution of the monasteries in Scotland and these religious communities declined more gradually than in other Protestant regions of Europe. The reformed monastic orders of the twelfth century revived the communal model of Benedictine monasticism and placed greater emphasis on poverty and manual labour in monastic life. Medieval monasticism was a pan-European phenomenon characterised by powerful monastic orders and shared value systems. How did medieval monasticism respond to local variations in belief, and to what extent did earlier, indigenous practices influence the local interpretation of monasticism? This question has been considered by monastic scholars in examining the role of monasticism as a tool of conquest and colonisation, for example in the context of the Baltic crusades in Central Europe, the Reconquista in Spain and Portugal, and the Anglo-Norman colonisation of Ireland (e.g. Pluskowski 20I7; Pluskowski et al. 20II; Lafaye 20I8). Here, the aim is to place the Scottish monastic experience in comparative perspective, in order to identify what is distinctive and significant about monasticism in twelfthcentury Scotland.

The archaeology of later medieval monasticism in Scotland remains a relatively under-developed field in comparison with many other regions of Europe. An archaeological research agenda is long overdue, but what factors have impeded its development? The subject has evolved in Scotland along a similar path to that travelled elsewhere in Europe: archaeological interest focused initially on the monastic core of the church and cloister, with more recent work expanding to include monastic landscapes, industry and buildings of the outer court (e.g. Hall 2006). The distribution of Scotland's monasteries was set out in the Atlas of Scottish History (McNeill and MacQueen I996) and relevant archaeological information on individual sites can be found on Canmore, the database of Historic Environment Scotland. Excavations have taken place on numerous sites, although mostly on a small scale (ScARF 20I2: I4), and important synthetic works on monastic archaeology and architecture were published over twenty years ago by Peter Yeoman (I995) and Richard Fawcett, respectively (I994a). Yet, despite significant investigations on individual sites and landscapes, monastic archaeology in Scotland lacks a critical framework of analysis to draw out its distinctive character. Nor has the study of religious institutions formed a major driver in shaping the archaeological research agenda for later medieval Scotland. Archaeological approaches to monasticism have remained principally descriptive and 
dominated by historical and architectural research questions. There has been relatively little interdisciplinary or theoretical engagement to address social questions about Scottish monasticism in the later Middle Ages or its wider material character.

In contrast, interdisciplinary studies have recently been undertaken on later medieval monasticism in Wales and Ireland. The 'Monastic Wales' and 'Monastic Ireland' projects feature web-based gazetteers that bring together historical and archaeological evidence for every monastic site and share them with a wide public audience. The 'Monastic Ireland' project contextualises monasticism at both the local and international level; for example, evaluating the extensive material remains of friaries in Ireland to consider how poverty was expressed through a distinctive mendicant materiality (KrasnodebskaD'Aughton and Lafaye 2018). The 'Monastic Wales' project aims to define Welsh monasticism in contrast to its English counterpart. The volume resulting from the project frames an important historical question which has immediate relevance to contemporary debates around Welsh national identity. It aims to explore the significance of monasteries in medieval Wales - how religious men and women shaped Welsh history and culture. Historical, archaeological and literary evidence is examined to begin to draw out the distinctive pattern of Welsh monasticism, and to make Welsh monasteries more 'visible', in terms of both scholarship and accessibility to a wider public (Burton and Stöber 20I3a: xvii). There is currently no sister project in Scotland to those on the Welsh and Irish monasteries.

Regional research frameworks for monastic archaeology are rare internationally, although critical overviews have been undertaken for France (Bonde and Maines I988, 2004) and Iceland (Kristjánsdóttir 2015a, 20I5b, 20I7; Monastic Iceland). In Italy, the archaeology of early medieval monasteries has been reviewed (Destefanis 20II), and the flagship project of San Vincenzo al Volturno (Hodges I997) has opened up new comparative perspectives (Augenti 20I6; De Rubeis and Marazzi 2008). Surveys of British monastic archaeology have tended to focus principally on England, with comparatively little coverage of Scotland and Wales (e.g. Bond 2004; Coppack I990; Gilchrist and Mytum I993; Greene I992; Keevil et al. 200I). Regional overviews of monastic architecture are more numerous but generally prioritise particular orders, such as the Benedictines, the Cistercians and the friars (e.g. Bruzelius 20I4; Carter 20I5a, 20I5b; Coomans 200I, 2004; Luxford 2005; Melville et al. 20I5; Stalley I987; Untermann 200I). The contemporary value and public visibility of monastic heritage has recently been addressed as part of European cultural patrimony (Coomans 2012; Coomans and Grootswagers 20I6; Noppen et al. 20I5), while historians have highlighted the role of monasteries as social and economic innovators in medieval Europe (Melville et al. 20I4). 


\section{IN THE SHADOW OF THE 'GOLDEN AGE'}

Why has the study of later medieval monasteries in Scotland failed to achieve a higher profile? Richard Fawcett argued that Scottish monasteries have been under-recognised due to the poor survival of architectural remains and because insufficient effort has been made to make information on them available. $\mathrm{He}$ also cited the historiographical tradition in Scotland: there was little interest in medieval architecture among Scottish antiquaries in the nineteenth century, in contrast with many other European traditions (Fawcett I994a: 9). Chris Dalglish made a similar point to explain the late development of scholarship on Scotland's medieval countryside more generally: archaeological interest in Scottish prehistory emerged in the nineteenth century but there was comparatively little interest in understanding the medieval landscape (20I2: 272). Scotland's medieval monasteries were also neglected by nineteenth-century, Presbyterian historians who were disinterested in Catholic heritage and viewed the reformed monasteries as morally corrupt, alien impositions. Their interest focused on the early medieval culdees, which were regarded as 'primitive and pure', and were considered to offer an historical precedent for Presbyterianism (Hammond 2006: 9). Scottish church studies were finally advanced in the I950s by the Scottish Catholic Historical Association, with the development of the Innes Review. Scottish monastic history has been dominated until very recently by nationalist perspectives which focused on the medieval struggle for independence from England - for example, Arbroath Abbey (Angus) attracted historical interest as the setting for the Declaration of Arbroath (I320), and Melrose Abbey (Scottish Borders) (Figure 2.I) as the resting place for the heart of Robert the Bruce (d. I329) (Jamroziak 20II: 35-7). The late Geoffrey Barrow (1924-2013) was influential in placing the history of the Scottish church and monasticism in a wider social framework, and recently historians including Emilia Jamroziak have situated Scottish monasticism in a comparative European context (Barrow I973, 2004b; Jamroziak 2008, 20II, 20I3).

Historiographical factors help to account for the late development of monastic studies in Scotland. But why does the subject continue to be neglected by archaeology? Why has medieval archaeology in Scotland failed to develop a critical framework for the analysis of later medieval monasteries? The crucial issue seems to be the role that Scottish national identity continues to play in selecting topics for archaeological study (Driscoll 20I0). Later medieval monasteries have been neglected in Scottish archaeology because a lower value has been placed on them by heritage professionals, academic researchers and members of the public. 'Value' in this sense refers to the social significance placed on archaeological remains and their potential contributions to contemporary communities, culture, economy and political debates (e.g. Klamer 20I4). 


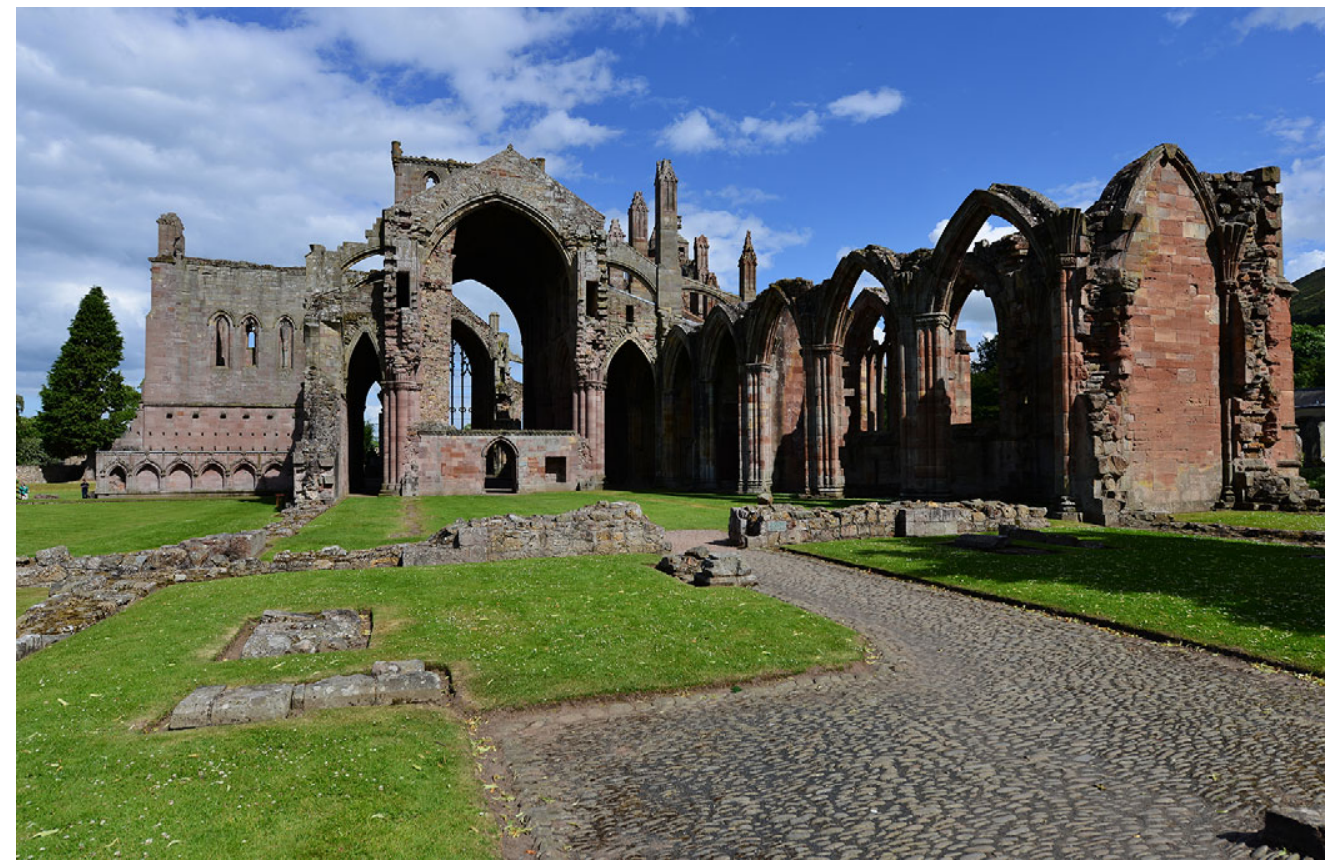

2. I Melrose Abbey (Scottish Borders). Photograph by Michael Garlick / Wikipedia / CC BY-SA 4.0

The 'social value' of heritage relates more broadly to 'people's sense of identity, distinctiveness, belonging and place, as well as forms of memory and spiritual association' (Jones and Leech 2015). There is little doubt that Scotland's later medieval monasteries have been overshadowed by those of its 'Golden Age', the so-called Celtic monasteries of the sixth to ninth centuries.

Island communities such as Iona (Scottish Inner Hebrides), with its charismatic founder-saint Columba (Colm Cille), have captured the imaginations of historians, archaeologists and the wider public, including advocates of contemporary spirituality termed the 'new Celtic Twilight' (Power 2006). As Iain MacDonald commented: 'Scholarship has been traditionally weighted towards the early medieval period, where the search for the elusive "Celtic" brand of Christianity dwarfs anything published for the period after IIOO' (20I4: I7). Archaeological study of Scotland's early medieval monasteries is thriving, signalled by landmark publications on Portmahomack (Easter Ross), Inchmarnock (Argyl and Bute) and the Isle of May (Fife) (Carver 20ı6; Lowe 2008; James and Yeoman 2008). These excavations revealed early monastic centres that excelled in manuscript production, monastic teaching, healing and pilgrimage. Christian sculpture remains the key indicator for identifying the sites of early monasteries in Scotland (e.g. Foster and Cross 2005), in contrast with the shift to the patronage of buildings that characterises later medieval monasteries. 
Scottish historiography bears close similarities with Ireland, where archaeological interests have focused predominantly on 'Ireland's Golden Age', c.500-900 CE. Early medieval monasteries have been valued as the apogee of native Irish culture, in contrast with later medieval monasteries that carry the negative overtones of Norman colonisation (O’Sullivan I998). Throughout the twentieth century, archaeological scholarship on medieval Ireland was dominated by the 'Golden Age' narrative (O'Sullivan et al. 20I4: 35). Even the most recent synthesis of archaeological excavations on medieval sites in Ireland covers the period up to c.IIoo (O'Sullivan et al. 20I4: 35), and there is no synthetic account for recent excavations on later medieval sites. The current 'Monastic Ireland' project, which focuses on the period IIOO-I700 CE, therefore represents a major step-change in scholarship and may signal a corresponding shift in the social and cultural value that is placed on Ireland's later medieval monastic heritage (Krasnodebska-D'Aughton and Lafaye 20I8). The focus on Scotland's 'Golden Age' is the legacy of a wider historical tradition that developed in the nineteenth century, beginning with the popularisation of Scottish history by Sir Walter Scott. The resulting narratives of medieval Scotland emphasise ethnic differences between Celtic and AngloNorman culture, a trope that was also explored by Welsh historians in the nineteenth century (Sims-Williams 1986). Matthew Hammond (2006) has examined the pervasive influence of this dualistic ethnic framework on the development and periodisation of Scottish history, which draws a sharp boundary at c.IIOo, separating Celtic Scotland of the eleventh century from Norman Scotland of the twelfth century. He argues that cultural and political projections of ethnic value that began in the nineteenth century continue to construct historical discourses around Scottish law, kingship, lordship and religion.

Within archaeology, the situation is exacerbated by the small number of later medievalists employed in Scotland. Later medieval archaeologists were appointed to posts in the Royal Commission on the Ancient and Historical Monuments of Scotland (RCAHMS) and the National Museum of Scotland, but they have been largely absent from university departments of archaeology. The higher value accorded to early medieval monasteries is reflected in the Scottish Archaeological Research Framework (ScARF 2012). This otherwise excellent document repeats the common tendency to under-value later medieval monasticism as a social and cultural phenomenon. Later medieval monasteries are omitted entirely from the chapter on 'mentalities' that addresses identity, ethnicity, gender and spirituality, although later medieval parish churches and pilgrimage are considered. Instead, later medieval monasteries are briefly cited for their potential to elucidate developments in agriculture and industry (ScARF 20I2: 48, 55). ScARF identifies priorities for future research on religion exclusively in the early medieval period, including early medieval 
sculpture, early churches, early cemeteries and the relationship of protohistoric settlement to prehistoric ritual landscapes and practices. The period up to the later eighth century is described as 'the most inventive religious phase in Scotland', when 'belief was regional and creative' (ScARF 20I2: 82). We can perhaps infer from its absence that archaeologists consider later medieval monasticism to be the inverse of the 'Golden Age', manifested by pan-European monastic orders such as the Cistercians, and lacking regional diversity, invention and creativity.

The research framework emphasises the importance of placing early medieval monasticism within a long-term perspective that connects it with prehistory, in the tradition of 'the long Iron Age' of Ireland and Scandinavia. This is informed by Martin Carver's compelling thesis that early medieval monastic practices in Scotland were influenced by prehistoric rites (2009). He notes precursors for early medieval monastic traits including the use of curvilinear enclosures, stone slab cist burials, stone markers and the curation of ancestral bones, which is continued in the Christian cult of relics. He concludes that early medieval people adopted archaic forms to reconcile changing beliefs and as a means of self-expression. Carver calls for early medieval monasticism to be placed within an interpretative framework that looks back at prehistory. In contrast, Stephen Driscoll argues for early medieval monasticism to be placed in a long-term perspective that looks forward towards the later Middle Ages and the modern, placing sites like early medieval Govan (Glasgow) in a framework of historical archaeology spanning I,500 years, from the sixth to the twentyfirst centuries (Driscoll 20IO).

Driscoll contends that national identity has influenced the Scottish archaeological research agenda and in particular the drive to demonstrate cultural distinctiveness from England (Driscoll 20I0: 443). The impact of national identity on the construction of archaeological knowledge helps to explain the low profile of Scotland's later medieval monasteries. They are accorded low cultural value because they do not figure in dominant discourses of Scottish heritage and national identity (Atkinson 1996). Reform monasticism of the later Middle Ages is often regarded as an English import - not an instrument of direct colonisation as it was in Wales and Ireland, but certainly not an expression of indigenous culture. The first step in developing a more critical framework for the study of medieval monasteries in Scotland is therefore to consider the construction of archaeological value in relation to national identity.

\section{'VALUE' AND THE CONSTRUCTION OF ARCHAEOLOGICAL KNOWLEDGE ON MEDIEVAL MONASTERIES}

How do later medieval monasteries look through the lens of archaeological 'value' that is projected in the Scottish Archaeological Research Framework? 


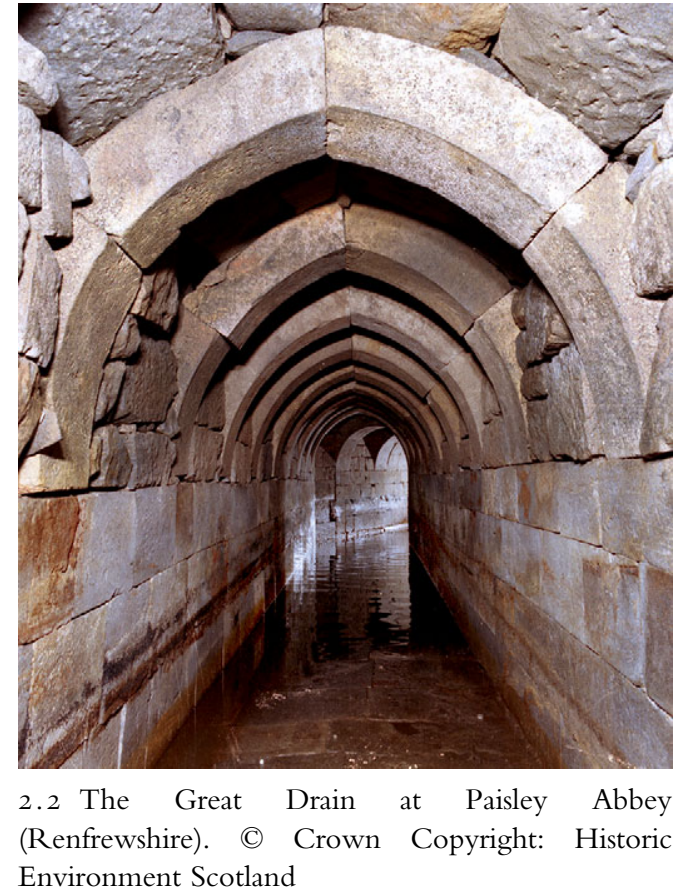

To what extent are they inventive, regional and creative'? Later medieval monasteries are typically characterised as innovators in economy and technology (e.g. Aston I993; Coppack I990). In Scotland, later medieval monasteries introduced coal mining, intensified salt panning and operated granges dedicated to ironworking, lead, silver and gold mining (Hall 2006); they developed new approaches to sheep and cattle farming based on the monastic system of granges (Fawcett and Oram 2004). They stimulated local pottery production in the twelfth and thirteenth centuries in areas that were previously a-ceramic, as suggested by excavations at Tironensian Kelso (Scottish Borders) and Cistercian Dundrennan Abbey (Dumfries and Galloway) (Lowe 2005: 33I; Ewart 200I: 39). And, of course, the often cited hallmark of monastic civilisation, they introduced high-quality plumbing and water management. This is vividly illustrated in Scotland by the superior engineering of the late fourteenth-century Great Drain of Paisley (Renfrewshire) (Figure 2.2), rediscovered in I990 (Malden 2000), and the unique survival at Cistercian Glenluce (Dumfries and Galloway) of earthenware pipes, still in situ where joints and inspection chambers are exposed to view (Canmore ID 6I2I4). However, the cultural contribution of Scotland's monasteries should not be overlooked, such as the essential role played by the friars in education and in the establishment of medieval universities at St Andrews, Aberdeen and Glasgow (Randla I999: 249). There were great libraries at the cathedral of St Andrews (Fife) and the monasteries of Kinloss (Moray), Deer (Aberdeenshire), Scone (Perth and Kinross), Cambuskenneth (Stirling), Melrose, Dryburgh (Scottish Borders) and Culross (Fife), the last with a scriptorium which produced books sold for commercial profit (Curran 20I5: 3I). In the fourteenth century, campaigns of rebuilding at Melrose, St Andrews and Paisley stimulated a distinctive Scottish architectural style that blended influences from France and the Low Countries to produce architecture quite distinct from that of contemporary England (Fawcett I994a: 76-8I).

The following chapters will explore the inventive contribution made by Scottish monasteries to medieval technologies of healing and magic. There is one important contribution that I would like to stress here: reformed 
monasticism was truly transformational in providing new opportunities for women in Scotland to engage actively in monasticism. The florescence of Scotland's 'Celtic' monasteries seems to have been reserved principally, if not wholly, for men. In contrast with the early medieval monastic traditions documented for Ireland, England and Francia (Bitel 20I3), there is little (documented) evidence for women's engagement with early monasticism in Scotland. The exception is the Northumbrian monastery at Coldingham (Scottish Borders), which followed the Anglian model of the double house: Bede records that it was in existence by the 660 s presided over by Abbess Æbbe (Cowan and Easson 1976: 47; Bartlett 2003). Excavations have confirmed the presence of a ditched enclosure at Coldingham dating from the seventh century and the presence of Anglian sculpture strengthens the identification of Coldingham as Æbbe's monastery (Stronach 2005).

The monasticism of the reformed orders channelled the agency of medieval Scottish women as founders, patrons, nuns and hospital lay-sisters. The turning point both for women and monasticism was the involvement of Queen Margaret, second wife of King Mael Coluim (Malcolm) III and daughter of Edward the Atheling, who was son of the Anglo-Saxon king of Wessex, Edmund Ironside (Barrow 2004a). Margaret spent her early life in exile in Hungary before returning to England with her family, who fled to Scotland in Io66. She was married at Dunfermline (Fife) in c. I070 to Malcolm Canmore. She introduced reformed monasticism to Scotland, assisted by Archbishop Lanfranc of Canterbury, who sent three monks from Canterbury Christchurch (Kent) to establish a Benedictine cell at Dunfermline. The historian Geoffrey Barrow (1973: 196) argued that Margaret was the catalyst for the comprehensive transformation of Scotland under her sons and grandsons, in which monasticism was a key tool in nation-building, particularly under Alexander I (IIO7-24) and David I (II24-53). The so-called Canmore dynasty has been viewed as the breakpoint between Celtic and Norman Scotland and the stimulus for Scotland's process of Europeanisation (Hammond 20I3: 2). Matthew Hammond (2006) has called for a critique of the Canmore concept and its impact on the periodisation of Scottish history. Nevertheless, the importance of Margaret as a religious innovator and role model for women remains convincing.

Margaret was buried in front of the high altar at Dunfermline, dying just three days after her husband was killed at Alnwick (Northumberland), in I093. For at least one hundred years prior to her canonisation c.1250, she was venerated by the gentry as a blessed intercessor and holy queen (Hammond 20IO). She is described as a servant of Christ and 'most pious mother', in Turgot's account of her life, written c. IIOO, suggesting that the cult of the Virgin Mary may have been influential in constructing popular devotion to Margaret. Based on her miracle stories, Robert Bartlett has described Margaret's cult as regional and with a strong masculine core (Bartlett 2003: xli). 


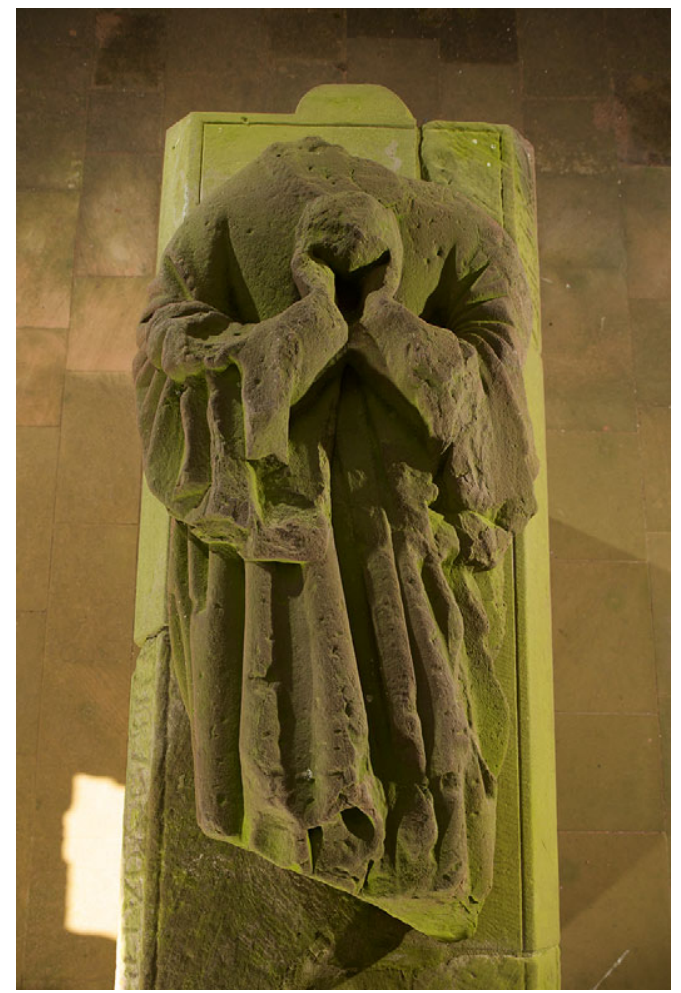

2.3 Tomb effigy of Lady Dervorgilla at Sweetheart Abbey (Dumfries and Galloway). (C) Crown Copyright: Historic Environment Scotland
However, she was specifically called upon to assist women in pregnancy and childbirth: several Scottish queens gave birth at Dunfermline in order to wear the relic of Margaret's birthing 'sark' or chemise (Bartlett 2003: xxxix). Margaret's example was followed by Scottish women who established monasteries in pious acts of commemoration. Examples include Matilda d'Aubigny, who was co-founder of the Augustinian monastery of Inchaffray (Perth and Kinross) c. I200, together with her husband Gille Brigte, Earl of Strathearn, in memory of their son Gille Crist (Veitch I999); Queen Ermengarde, wife of William the Lion, who established the small Cistercian abbey at Balmerino (Fife) c. I227 and was buried there (Hammond 20I0: 74); and the romantic Lady Dervorgilla of Galloway, who founded Cistercian Sweetheart Abbey (Dumfries and Galloway) in I273 in memory of her husband, John Balliol. The abbey was named in reference to his embalmed heart, which resided in an ivory casket bound with enamelled silver. Dervorgilla was buried with the casket in the sanctuary of the monastic church at Sweetheart Abbey and she is depicted on her effigy holding the heart (Richardson 2006: 20) (Figure 2.3).

Scotland's fifteen medieval nunneries were dismissed by twentieth-century historians as relatively poor and small (Cowan and Easson 1976: xii; Dilworth I995). The emphasis on national politics in the historical study of Scottish monasticism (discussed above) has placed religious women at the margins of scholarship. Revisionist histories of medieval religious women have been written across Europe over the past forty years: the first historical study of Scottish nunneries was completed in 2005 by Kimm Curran (Curran 2005). Previous scholarly neglect of Scottish nunneries reveals a misunderstanding of the role and scale of institutions for medieval religious women, which were typically established to have a close relationship with the founding family rather than a national role (Gilchrist I994). Prosopographical analysis confirms that Scottish nuns were recruited from the immediate locality of the nunnery, or were related either to the nuns or their tenants living on the monastic estate (Curran 2005: I48) (Figure 2.4). The Augustinian nunnery at Iona (Figure 2.5) 

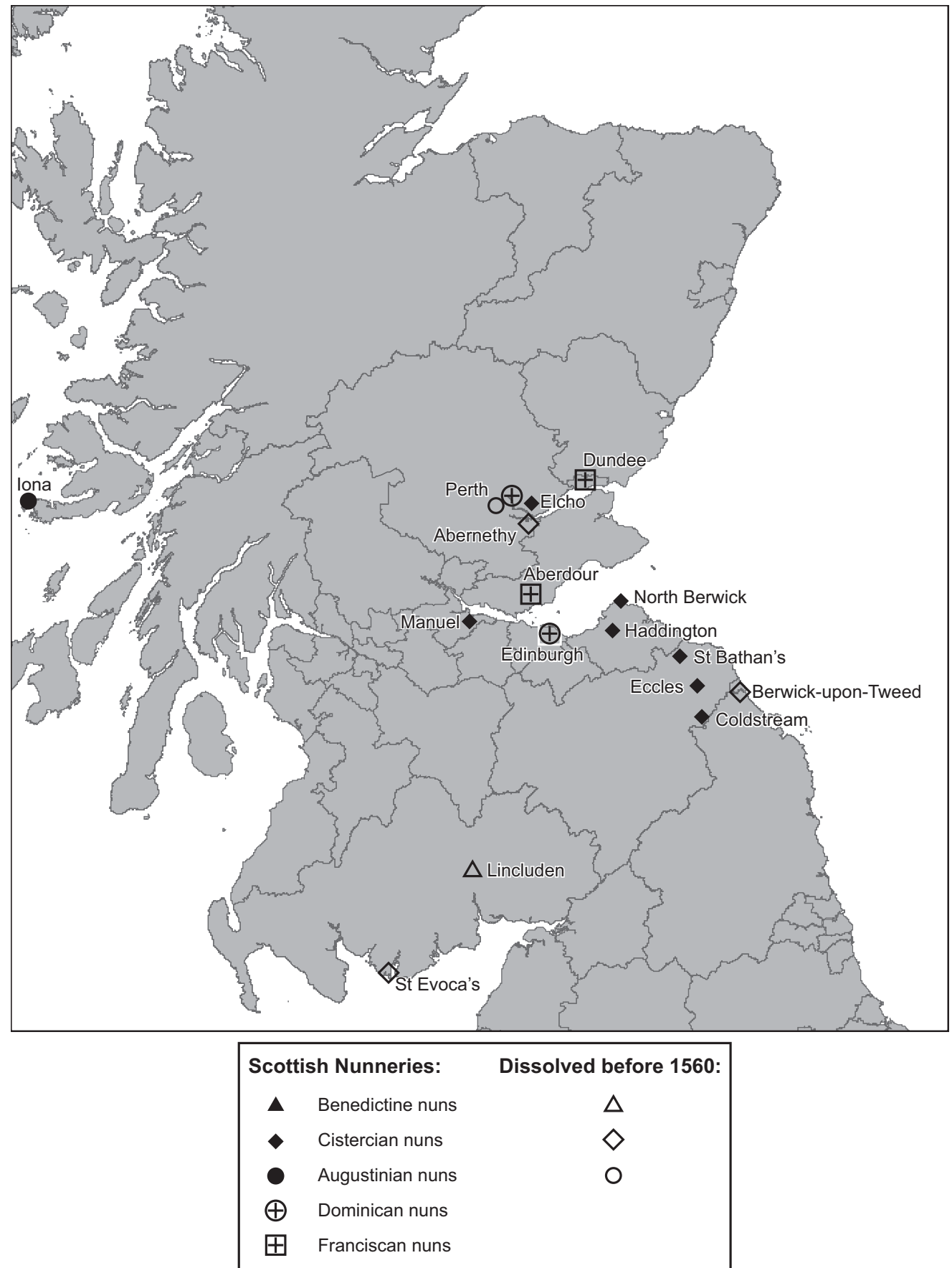

2.4 Map showing the location of medieval nunneries in Scotland (c.II50-I560). After McNeill and MacQueen 1996 (C) Sarah Lambert-Gates 


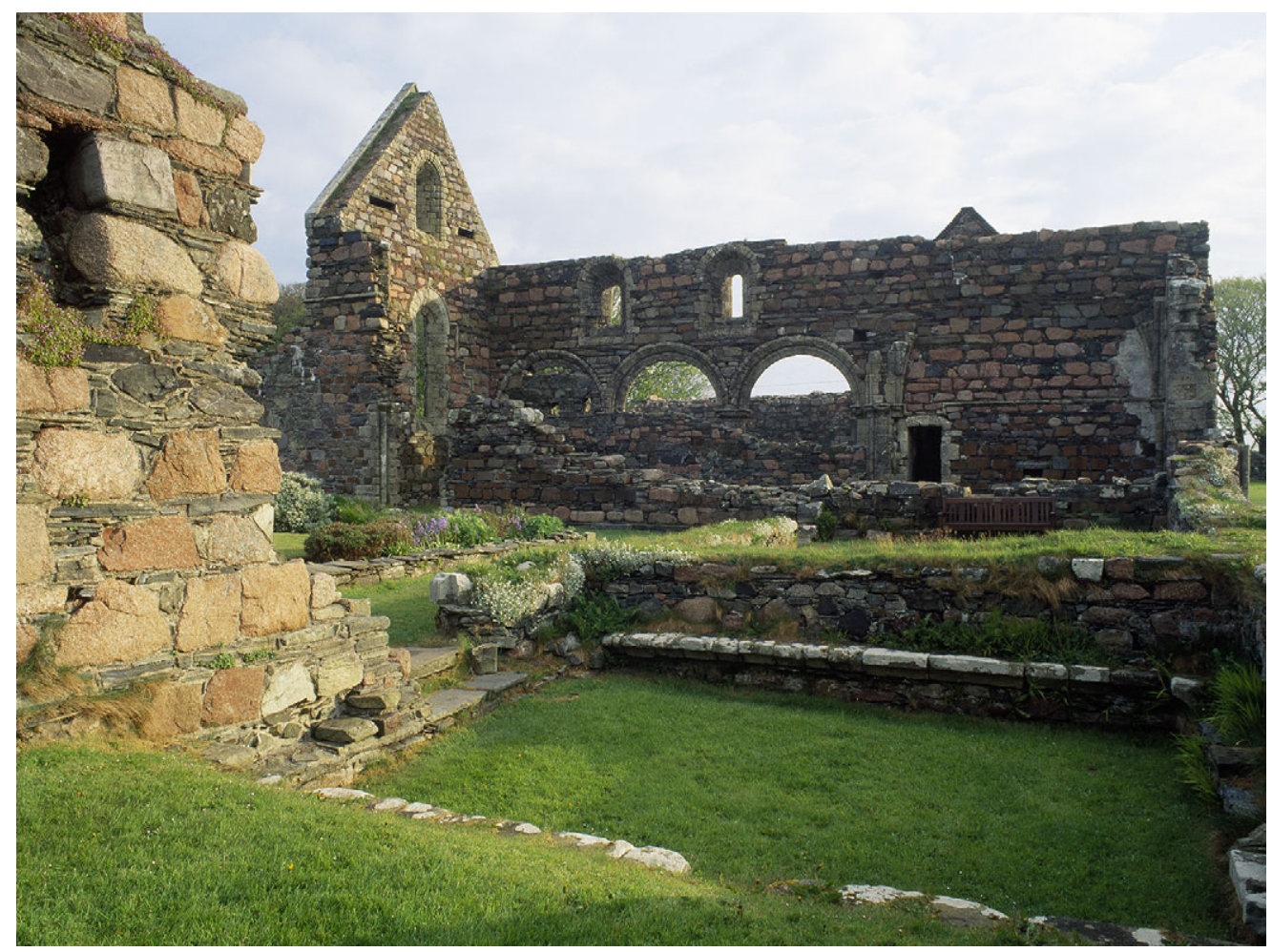

2.5 Iona Nunnery (Scottish Inner Hebrides). (C) Jean Williamson

was founded by Raghnall mac Somhairle in I203, close to his foundation of the Benedictine monastery at Iona, and his sister, Bethóc, became the first prioress (Ritchie 1997). The well-preserved buildings of Iona compare favourably with surviving nunnery architecture in England, Ireland and Northern Europe, in terms of the quality and scale of architecture. Like their male counterparts, Scottish nunneries also promoted industry: the only example of a medieval tile kiln excavated in Scotland was in the grounds of the nunnery at North Berwick (East Lothian), which produced highly decorated floor tiles (ScARF 2012: 99; Hall and Bowler 1997).

The partially excavated site of the Cistercian nunnery of Elcho, outside Perth, is thought to have been founded in the thirteenth century by David Lindsay of Glenesk and his mother, Lady Marjory (Cowan and Easson I976: I46). The site has yielded imported pottery comparable to that of the burgh of Perth and religious material culture including paternoster beads and window glass. There were three copper alloy book clasps, a mount possibly from a book cover, a nun's grave slab with inscription, and the base of a hanging bronze oil lamp (Reid and Lye 1988: 70) (Figure 2.6). This may appear on first glance to be a fragmentary assemblage, but it is actually a unique group of finds representing literacy from a British nunnery. Even thoroughly excavated 

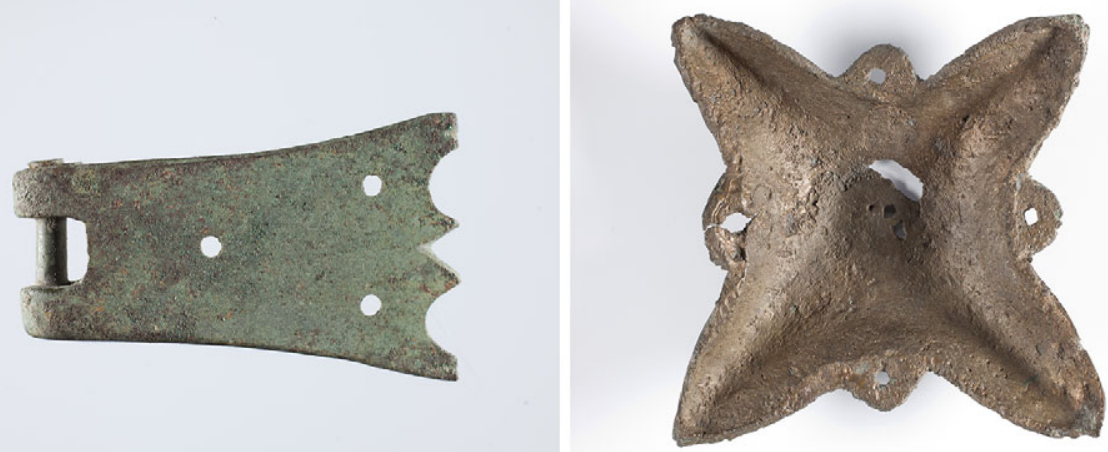

2.6 Book clasp and oil lamp from Elcho Nunnery (Perth and Kinross). Clasp: $30 \times 22 \times 4 \mathrm{~mm}$; lamp: $201.5 \times 54 \times 20 \mathrm{~mm}$. Images courtesy of Culture Perth \& Kinross

English nunneries, such as St Mary Clerkenwell in London, have failed to produce material culture confirming literacy (Sloane 20I2: I60). This contrasts with the rich assemblages of literary material culture that are typical of male religious houses, indicating that literacy was an important technology in shaping monastic experience (Egan 1997). The archaeological evidence for literacy at Elcho is a significant commentary on the spiritual life of Scotland's nunneries and the new opportunities that they provided for religious women. A number of books also survive from Scottish nunneries, including the Iona Psalter, the Sciennes Psalter, an English Bible from Elcho and a possible missal fragment from Lincluden (Dumfries and Galloway). The literacy of Scottish nuns may also have served a broader social purpose: Curran concludes that members of the laity were sent to the nunneries of Haddington (East Lothian), Elcho and Aberdour (Fife) to receive an education from the nuns (Curran 2015: 25).

\section{MONASTICISM AND NATION-BUILDING}

How did monastic foundations contribute to nation-building and to what extent was the Scottish experience distinctive? The Scottish Archaeological Research Framework identifies state formation as one of the key questions for future research in Scottish medieval archaeology: 'understanding why, where and how' Scotland emerged (ScARF 2012: i). Medieval monasteries were critical to Scottish nation-building in the twelfth and thirteenth centuries and their role in this process can be clarified in comparison with other regions of Britain and Europe. First, what did Scottish monasticism look like in the late eleventh century, on the eve of monastic reform? Monasteries of the 'Golden Age' had largely disappeared by the ninth century, such as Pictish Portmahomack, although communities of monks evidently survived. Sculpture dating to 


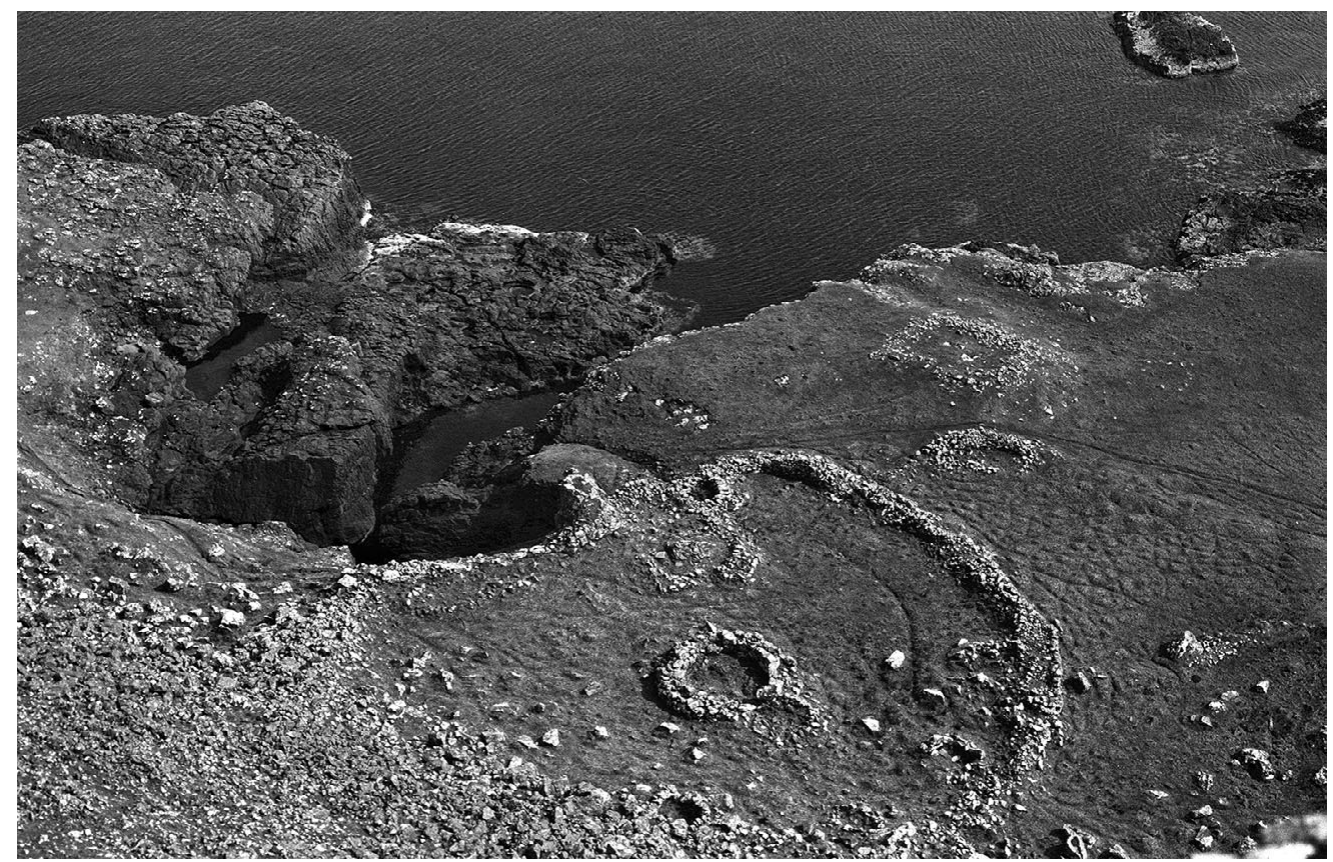

2.7 Early monastic settlement at Sgòr nam Ban-Naomha ('Cliff of the Holy Women'), Canna (Scottish Inner Hebrides). (C) Royal Commission on the Ancient and Historical Monuments of Scotland

the tenth and eleventh centuries suggests the location of religious communities, for example an exceptional cross-slab at Dunkeld (Perth and Kinross) (Macquarrie I992: I22). Turgot, the biographer of Margaret, described religious life in Scotland as 'very many men shut up in separate little cells in various places, who though they were living in the flesh practised denial of the flesh through extreme asceticism' (Barrow I973: 190). His description may have been intended for political reasons to minimise the importance of monastic life before Margaret. Nonetheless, it places an important emphasis on the eremitic character of Celtic monasticism - a desert monasticism of the north Atlantic. In eleventh-century Scotland, eremitic monasticism was represented by both individual hermits and island communities of ascetic monks. It is likely that these communities continued to follow the Irish monastic lifestyle, living in individual cells such as those on Canna at Sgòr nam Ban-Naomha (Scottish Inner Hebrides), comprising the ruins of beehive cells in a stone enclosure (Dunbar and Fisher 1974) (Figure 2.7). Early churches have been excavated on the Isle of May and Iona (St Ronan's). Dating to the tenth century, these first stone structures were bonded in clay and built on a modest scale to accommodate small communities at worship (c. $3.5 \mathrm{~m} \times 4 \mathrm{~m}$ internally) (Yeoman 2009).

There were communities of priests or clerici in eleventh-century Scotland who seem to have fulfilled some type of pastoral role and there were also 


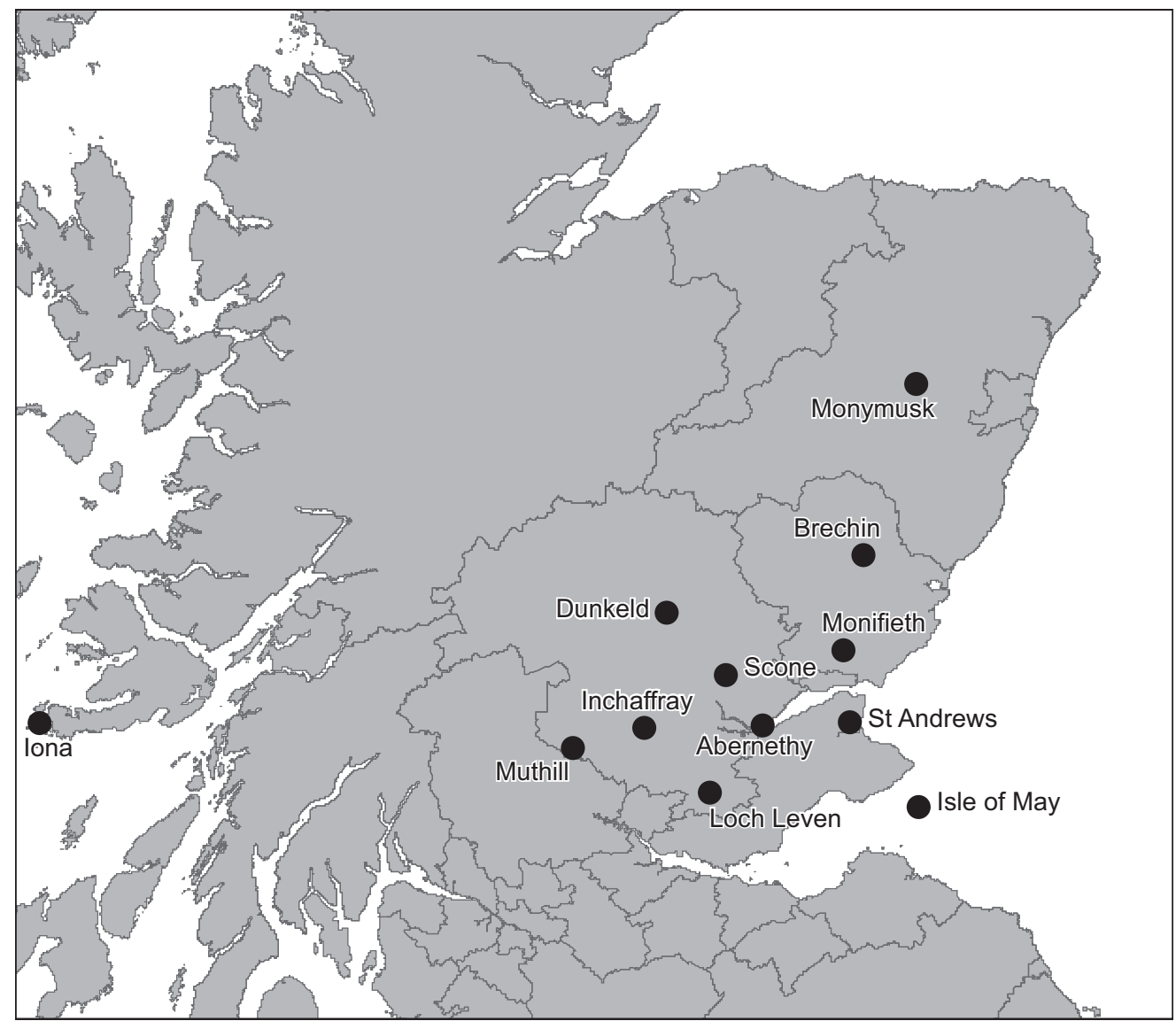

2.8 Map showing culdee and early monastic sites in Scotland (Ioth-IIth centuries). After McNeill and MacQueen 1996 C Sarah Lambert-Gates

eremitic monks - the shadowy culdees, or Céli Dé. The term means companions or clients of God and was originally reserved for an elite class of eremitic monks and hermits. The reform movement of the Céli Dé originated in Ireland and was introduced to Scotland via Iona in the early ninth century (Clancy I999). By the tenth or eleventh century, there were eremitic Céli Dé at remote sites such as Inchaffray and Loch Leven (Perth and Kinross), which Turgot records as receiving patronage from Margaret (Figure 2.8). However, the term Céli Dé was also applied to communities of priests, such as those serving the episcopal church at St Andrews, which appears to have comprised a group of married clergy based on hereditary succession (Macquarrie 1992). From the tenth to the thirteenth centuries, the term Céli Dé encompassed a wide diversity of monastic experience in Scotland (Clancy I999). It seems that the spiritual needs of rural communities to the north of the Forth were served by the secular priests of monasteries that also incorporated Céli Dé, while the south followed the Northumbrian model of quasi-parochial minsters served by 
priests, such as Whithorn (Dumfries and Galloway) (Barrow 2004b: 592). There was nothing in Scotland that resembled the reformed, western monasticism of France and England; there was no regulation by bishops and very little contact with the papacy. The changes experienced by Scotland in the twelfth century were part of a wider pattern across Europe, in which local churches became more centrally controlled by Rome and local rulers used monasteries to consolidate their own power.

In Normandy, for example, the Norman dukes restored ancient monasteries that had been destroyed by their Viking grandfathers. Cassandra Potts argues that monasticism was central in forging Norman regional identity in the tenth and eleventh centuries. The dukes of Normandy appealed to local loyalties by rebuilding monastic heritage, reviving the cults of Merovingian saints and supporting the emergence of the reformed monastic orders. Monastic patronage was fundamental to transforming the perception of these rulers from Viking marauders into Norman princes (Potts 1997: 133-7). The Normans extended this strategy to England as part of the Conquest: William used Norman monasticism as an instrument of colonisation and consolidation in England, establishing new foundations and planting Norman monks in ancient monastic foundations such as Canterbury (Kent), Durham (County Durham) and Glastonbury (Somerset), in order to appropriate Anglo-Saxon sacred heritage. This process also involved major campaigns of rebuilding to establish the claustral plan at English monasteries. There is no archaeological evidence for a monastic cloister in England before the Norman Conquest - the commonly cited example of Glastonbury has recently been disproven by reanalysis of the archaeological archive (Gilchrist and Green 20I5; see Chapter 6).

It is this Norman model of a Christian kingdom that was adopted by Scottish kings and Gaelic nobles in the twelfth and thirteenth centuries. Reformed monasticism was not imposed on Scotland; instead, the monastic cultural package was adopted as part of a proactive strategy of state-making that was intended to create a unified, European-style kingdom (Stringer 2000: I27). The establishment of a monastery conferred social status and prestige on the founder and identified them as a true Christian king or queen. For Kings Alexander I and David I, founding monasteries was a way of consolidating the kingdom of Scotland and bringing it into the mainstream of European culture (Jamroziak 20II: 47). Their foundations sustained close connections to the royal house by serving as royal mausolea, particularly Margaret's foundation of Benedictine Dunfermline (c. I070) and David's foundations of Cistercian Melrose (c. II36) and Augustinian Holyrood (Edinburgh; II28). Royal palaces were also established at the monasteries of Dunfermline and Holyrood, which were foci for royal ceremony such as weddings and funerals (Ewart and Gallagher 2013). Burial practices reflect the close association of Melrose Abbey with royal and noble benefactors, in contravention of 
Cistercian ordinances. Melrose permitted secular burial in the east end of the church in the twelfth and thirteenth centuries, in contrast with the strict observance of its mother house at Rievaulx (North Yorkshire), which did not permit lay burial until the mid-fourteenth century (Jamroziak 20II: 98-9). The burial of women was documented at Melrose in the thirteenth century and excavations in the chapter house uncovered a female interment in a sandstone coffin (Ewart et al. 2009: 269). In this respect, Scottish Cistercians were similar to those in Denmark, who welcomed the early burial of secular elites from the late twelfth century (McGuire I982). The act of monastic foundation in Scotland was the exclusive preserve of the laity, in contrast with parts of Northern Europe and the Baltic, where bishops were often the key drivers of monasticism and the process of Europeanisation (Blomkvist 2004). Scandinavian kings and bishops established monasteries from the twelfth century in emulation of the 'Catholic core' of Europe (Nyberg 2000).

Monasticism in Scotland was rapidly transformed by the energy of the Canmore house, which spread its patronage widely (Figure 2.9). David I founded four Cistercian monasteries, three Augustinian, two Tironensian, two Benedictine and one Premonstratensian monastery; he established the first nunnery and introduced the Knights Templar and Knights Hospitaller to Scotland (Cowan and Easson I976: 6). These monasteries had strong AngloNorman associations - they were often the daughter houses of English monasteries and staffed by English monks. They have therefore been regarded as a foreign (English) introduction, along with other aspects of feudalism established in twelfth-century Scotland such as burghs, sheriff courts and coinage. Recent historical research cautions against the simplistic binary framework of Gaelic $=$ old versus Anglo-Norman $=$ new, and the associated projections of cultural value that these ethnic oppositions promote (Hammond 20I3). For instance, the Gaelic nobility founded monasteries and enrolled their sons and daughters as monks and nuns, while the local peasantry would have provided lay-brothers for Cistercian and Premonstratensian abbeys and lay-sisters for hospitals (Stringer 2000: I53).

Royal patronage was the catalyst for rapid growth in Scottish monasticism from IIO0-65, followed by a period of fifty years of consolidation when new foundations were established by earls and magnates (Hammond 2010: 75). Gaelic nobles adopted the same cultural model of the Christian prince as monastic founder, perhaps in direct competition with the Canmores. Although Scotland in the twelfth century was united under a common monarch, it was still a highly fragmented nation (Broun 2007). In the west of Scotland, the Gaelic-Norse ruler, Fergus, Lord of Galloway, was associated with the foundation of two Cistercian, three Premonstratensian, one Augustinian and one Benedictine monasteries (Stringer 2000: I28). Gaelic nobles sponsored the conversion of Céli Dé into Augustinian communities, such as 


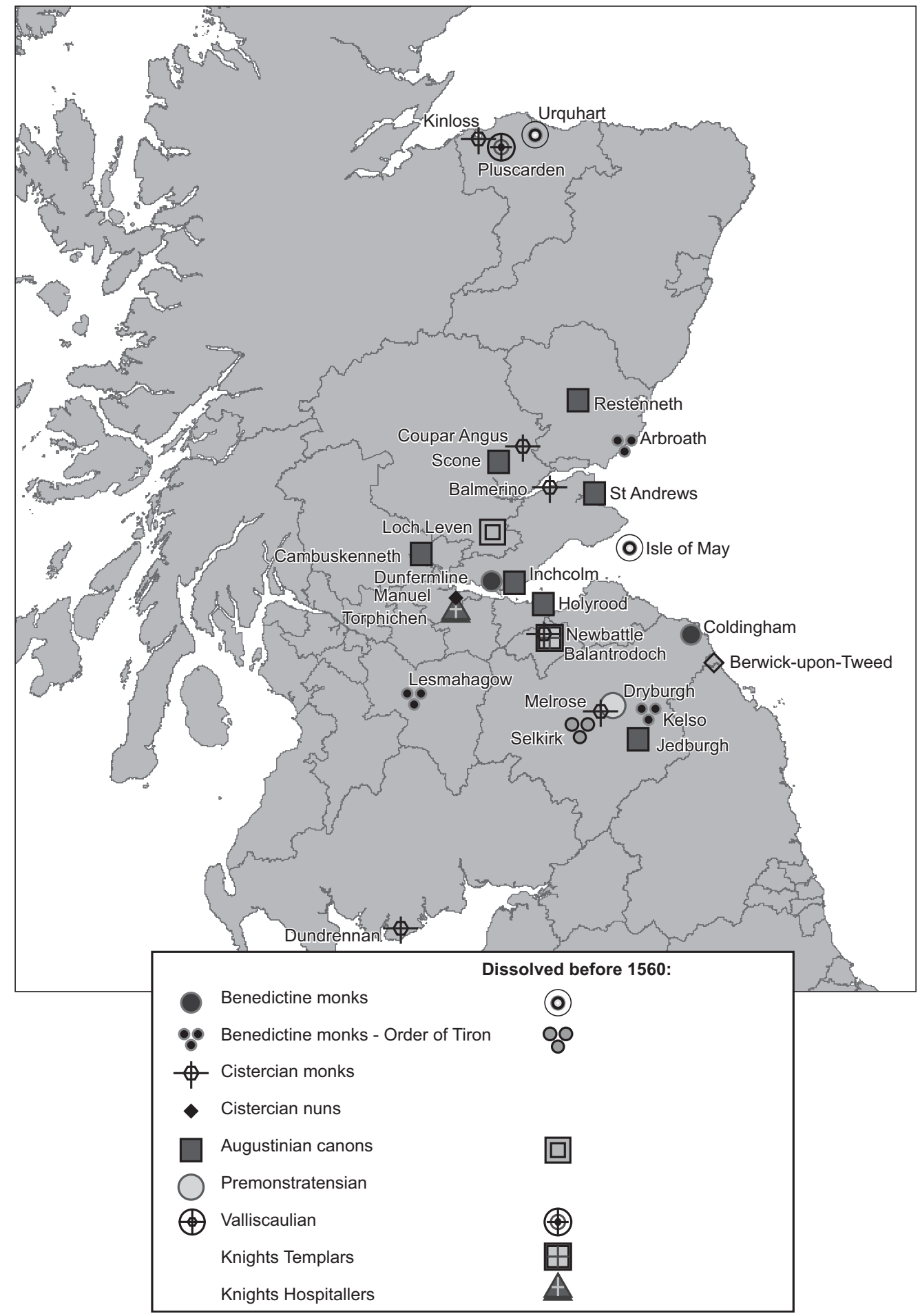

2.9 Map showing monasteries founded by the Canmore dynasty (I058-I286).

After McNeill and MacQueen 1996 (C) Sarah Lambert-Gates 
Earl Gille Brigte of Strathearn and Earl Gille Crist of Mar, respectively founders of Augustinian Inchaffray and Monymusk (Aberdeenshire), c. I200 (Veitch I999: 2 I). A similar process was underway in Wales, where the sites of ancient Welsh Céli Dé were transformed into Augustinian monasteries by the royal house of Gwynedd, described by Karen Stöber and David Austin as a strategy 'to reform the practices of their cultural church and bring it more into line with European norms of monasticism' (Stöber and Austin 2013: 46). The Irish church became receptive to external influences from the mid-eleventh century and began the 'de-tribalisation of ancient monasteries', followed by the foundation of large numbers of new Cistercian and Augustinian monasteries in the twelfth century (Barrow 2004b: 602).

A defining characteristic of twelfth-century monastic foundations in Scotland was the appropriation of indigenous sacred heritage: reformed monasteries were created at ancient holy places and new foundations actively promoted Pictish and Celtic saints, alongside the new emphasis placed on Christ, the Holy Trinity and the Virgin Mary (Hammond 20I0). Alexander I introduced the Augustinians to the ancient see of St Andrews and established the cathedral priory as Scotland's chief ecclesiastical centre. He also created an Augustinian priory at Scone (Perth and Kinross), a locale resonating with religious and political significance, as the ancient inauguration site of Scottish kings. Fergus of Galloway is credited with the transformation of Whithorn, the shrine of St Ninian's cult, into a cathedral priory staffed by the austere Premonstratensian order. David I gave the Celtic shrine on the Isle of May to the Benedictines of Reading Abbey, the foundation of his brother-in-law, the English King Henry I. David established new monasteries on or near the sites of Anglian minsters at Melrose and Jedburgh, respectively Cistercian and Augustinian foundations.

The reuse of ancient sites sometimes required adaptation and complex engineering to accommodate the claustral plan that was synonymous with reformed monasticism. For example at Jedburgh (Scottish Borders), excavations have shown that the choice to build on a steep river bank required the construction of terraces cut into the river bank to provide a level platform for the claustral complex. Siting of the cloister was clearly determined by the desire for visibility and dominance over the landscape. The cliff face was consolidated to protect the buildings close to the river and the Jed Water had to be diverted before the south range of the cloister could be built (Lewis and Ewart 1995). Why was it critical for monasteries of the reformed orders to be based around cloisters, even where sites were not well suited topographically? In functional terms, the cloister integrated four ranges of buildings and provided covered access between them. The cloister was also a powerful symbol of coenobitic monasticism and the Benedictine ethos of communal living. It represented a firm rejection of earlier forms of Celtic, eremitic monasticism, in which cells for solitary monks were arranged in concentric enclosures. 
The cloister drew on Roman archetypes including courtyard houses and the galleried atria of basilican churches in Rome, and thus carried resonances of the Roman church. Its walks served as a performative space for processions, enhancing the monastic liturgy and integrating the church with the domestic buildings. It was connected to monastic ritual through observances carried out at the lavatorium, the washing place at the entrance to the refectory. It was the centre of daily life for the monks (or nuns) as well as a place of learning and contemplation, with carrels or benches provided for individual study (Gilchrist I995: 66, 77-93). For example, the remains of seating can be detected in the cloisters at Inchcolm (Fife), Melrose and Iona (Curran 2015: 29). The cloister was at the same time a metaphorical space: the garden in the central space of the cloister garth represented the heavenly paradise that was the subject for monastic contemplation (Cassidy-Welch 200I: 48). The cloister served as a focus for monastic memory, with imagery selected to prompt monastic meditation and to evoke religious meaning (Carruthers 2000: I6). For example, the sequence and iconography of the historiated cloister bosses at Norwich Cathedral reinforced monastic concepts of time and communal history (Gilchrist I995: 253-7). More than any other feature of monastic architecture, the cloister constructed embodied experience, bringing together material culture with monastic techniques of the body, including liturgical ritual, literacy and memory practices.

Even the oldest Celtic monastery in Scotland was subject to re-foundation at the close of the twelfth century: the sacred site of Iona, founded $563 \mathrm{CE}$, was the last to survive before its reform. As well as housing the shrine of St Columba, Iona was the burial place of Scottish kings until the late eleventh century, when it was eclipsed by Dunfermline. A Benedictine monastery was established at Iona c. I200 by Ranald (Rognvaldr), son of Somhairle, a GaelicNorse warlord who had seized control of the Kingdom of the Isles in the midtwelfth century (Figure 2.IO). The enclosure (vallum) of the early monastery at Iona is well-preserved and the remains show that Ranald was determined to stamp his new Benedictine cloister onto the centre of the ancient complex. The Irish familia of Columba are reported to have burnt down the new Benedictine monastery, while a contemporary poem laments the arrival of foreigners and records the cursing of the Somerled line (Hammond 20I0: 83). However, Ranald's monastery evidently aimed to appropriate and promote the cult of Columba, rather than suppress it. The sanctity associated with St Columba and his grave-site was harnessed for the new Benedictine foundation by maintaining spatial continuity of place with its Celtic precursor.

Archaeological evidence suggests that the fabric of the existing shrine of St Columba was incorporated into the new Benedictine complex, tucked between the west end of the church and the west range of the cloister. This tiny chapel $(4.3 \mathrm{~m} \times 3.2 \mathrm{~m})$ was rebuilt in the $\mathrm{I} 960 \mathrm{~s}$ but the original walls 


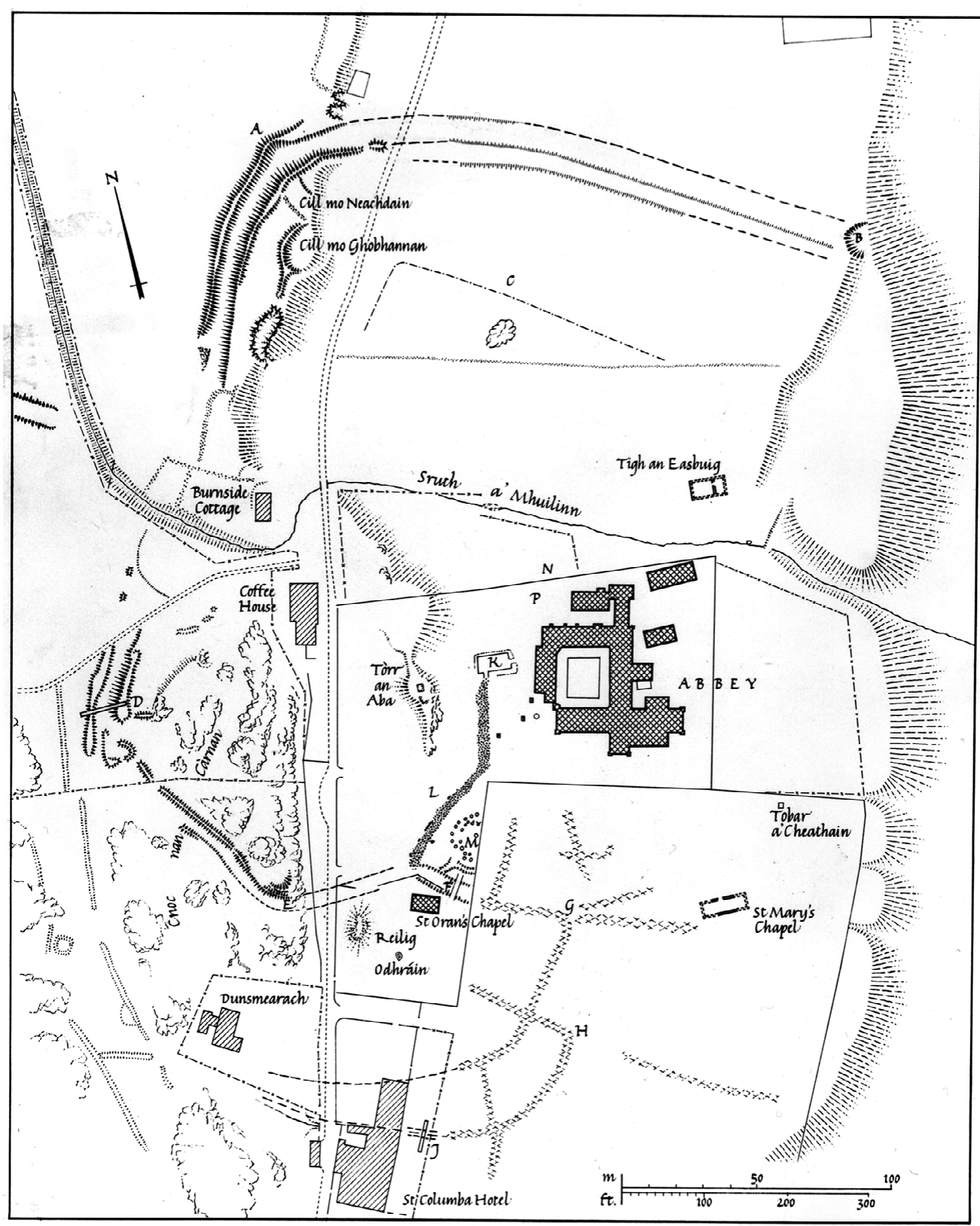

2. I o Plan of Iona Abbey (Scottish Inner Hebrides). (C Royal Commission on the Ancient and Historical Monuments of Scotland

survived to I $\mathrm{m}$ in height in the nineteenth century (Ritchie I997: 98). The antae of the shrine chapel survive at the northwest and southwest corners, a feature of early Irish churches in which the side walls project (RCAHMS I982: $4 \mathrm{I}-2)$. Columba's Shrine at Iona is the only extant example in Scotland of this characteristically Irish feature, which was also identified in excavations at 
Chapel Finian (Dumfries and Galloway), which dates from the tenth or eleventh century (Radford I95I). Excavations at Iona have confirmed that the shrine pre-dates the Benedictine church. The shrine attracted other commemorative monuments, such as three high crosses and a stone-lined well (O'Sullivan 1999: 220). Excavations in the nave during the early twentieth century revealed traces of earlier structures associated with burials containing quartz pebbles (Yeoman 2009: 229). It is possible that the thirteenth-century crypt beneath the east end of the Benedictine church also incorporated earlier fabric. Reuse of parts of the existing church at Iona required compromises to be made in the Benedictine claustral plan: the cloister was placed to the north of the church, in contrast with the usual arrangement of a south cloister (Ritchie I997: I05).

By I200, the diverse forms of eremitic monasticism in Scotland had been replaced by liturgical uniformity and the Benedictine model of communal monasticism. The Church of Scotland was organised into dioceses led by a bishop and a direct connection had been established to the pope, with the Scottish church christened as the 'special daughter' of the Roman see (Barrow 2004b: 592). Scottish patronage had shaped a unique mix of monastic orders (Figures 2.II and 2.I2) showing a strong French influence: for example, the Tironensians favoured by David I were extremely rare outside France, and the obscure Valliscaulians were exclusive to France and Scotland. English monasticism was dominated by the Benedictines, while Scotland was principally Augustinian and Cistercian (Dilworth I995). A new phase of religious reform around I230 took place under Alexander II (I2 I4-49), with the establishment of the friaries and the introduction of the austere Valliscaulian order at Pluscarden (Moray) (Hammond 20I0: 75). The Scottish Wars of Independence resulted in the repeated devastation of monasteries in the fourteenth century, particularly in the Borders, but there was a resurgence of monastic foundations in the more prosperous period of the fifteenth and sixteenth centuries. A highly distinctive pattern of Scottish monasticism is the vibrancy of late mendicant foundations, with new friaries founded right into the sixteenth century (Randla I999: 246), in contrast with the situation in England, Wales and Ireland (Figure 2.I3).

\section{SCOTTISH MONASTIC REFORM: THE CONVERSION OF}

THE CÉLI DÉ

State-building in medieval Europe was often supported by a process of monastic foundation that revived or appropriated the sites of ancient monasteries. What was the material manifestation of this cultural transformation and how did it impact on Scotland? Were the culdees (Céli Dé) and other early monasteries suppressed or absorbed? How did the appropriation of sacred heritage involve the preservation, destruction or modification of ancient sites? Considerable 


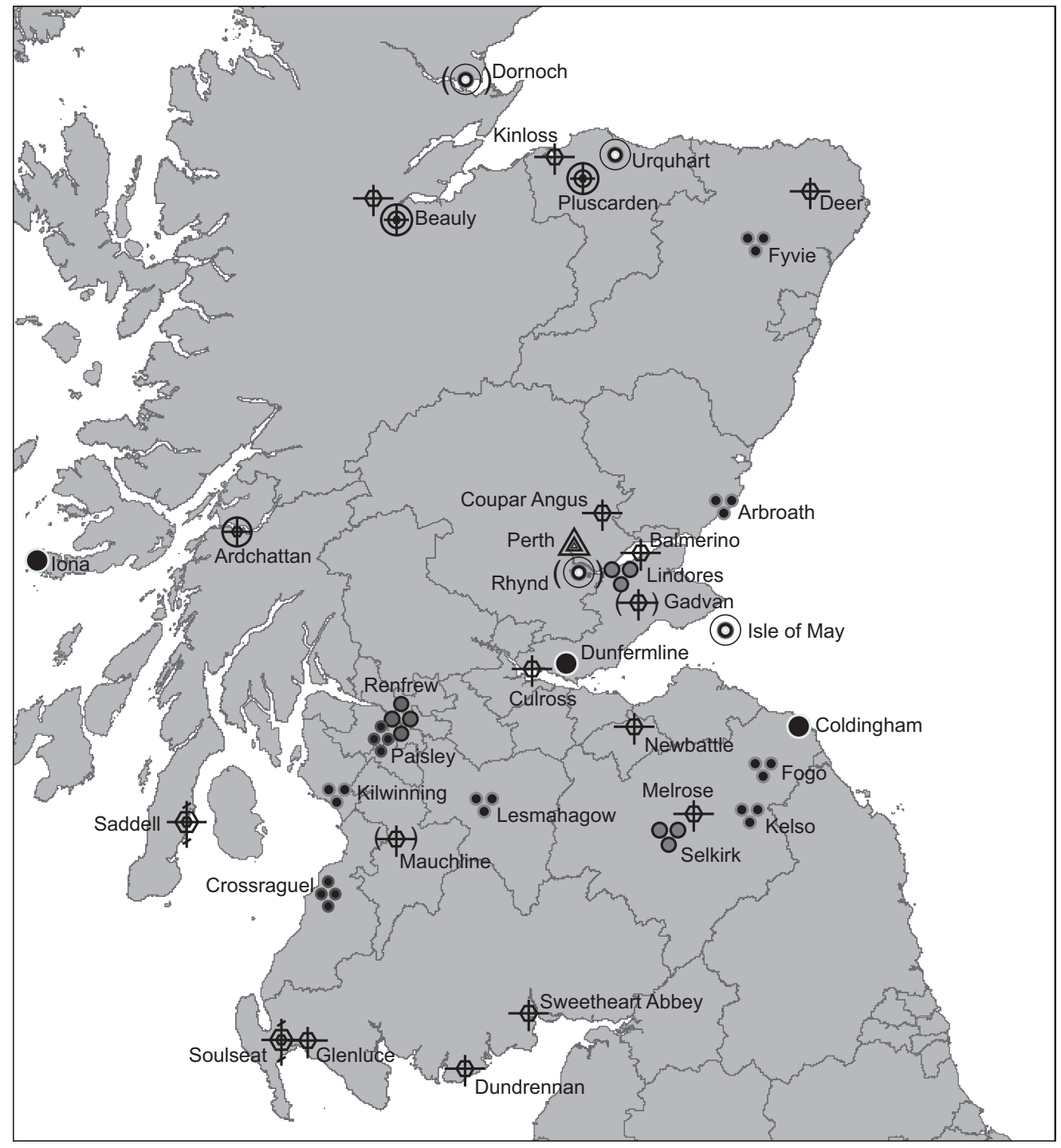

\section{Monastic Orders I}

Benedictine monks

Q. Benedictine monks - order of Tiron

8 Benedictine monks - order of Cluny

† Cistercian monks

( Valliscaulian

$\triangle$ Carthusian
Dissolved before 1560:

()

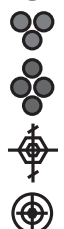

(9)

*Symbols in brackets indicate small or indefinite foundations

2. I I Map showing the location of later medieval monasteries in Scotland (I089-I560): Benedictine, Cistercian, Valliscaulian and Carthusian. After McNeill and MacQueen I996 C Sarah Lambert-Gates 

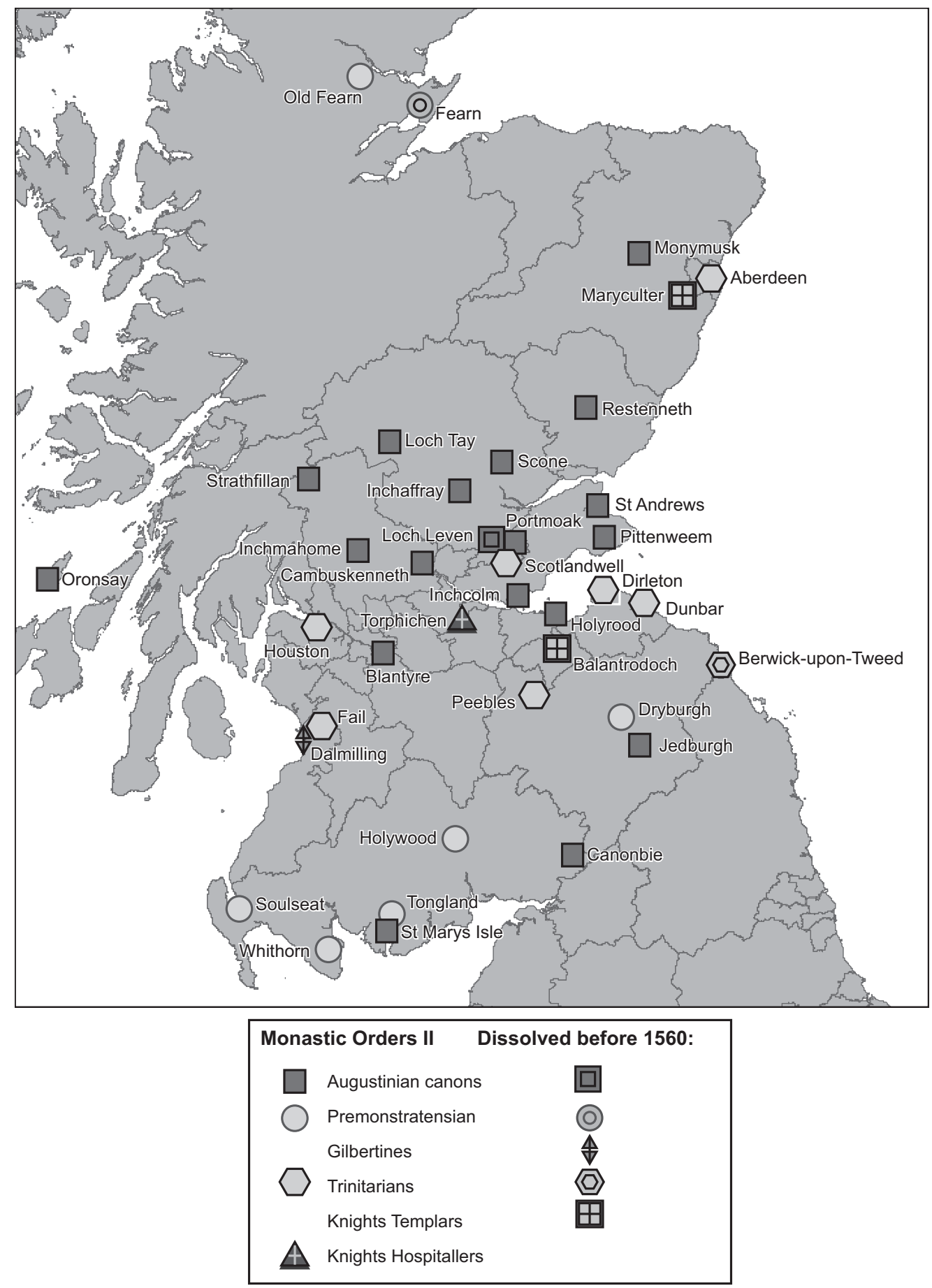

2. I Map showing the location of later medieval monasteries in Scotland (I089-I560): Augustinian, Premonstratensian, Gilbertine, Trinitarian, Knights Templar and Hospitaller. After McNeill and MacQueen I996 C Sarah Lambert-Gates 

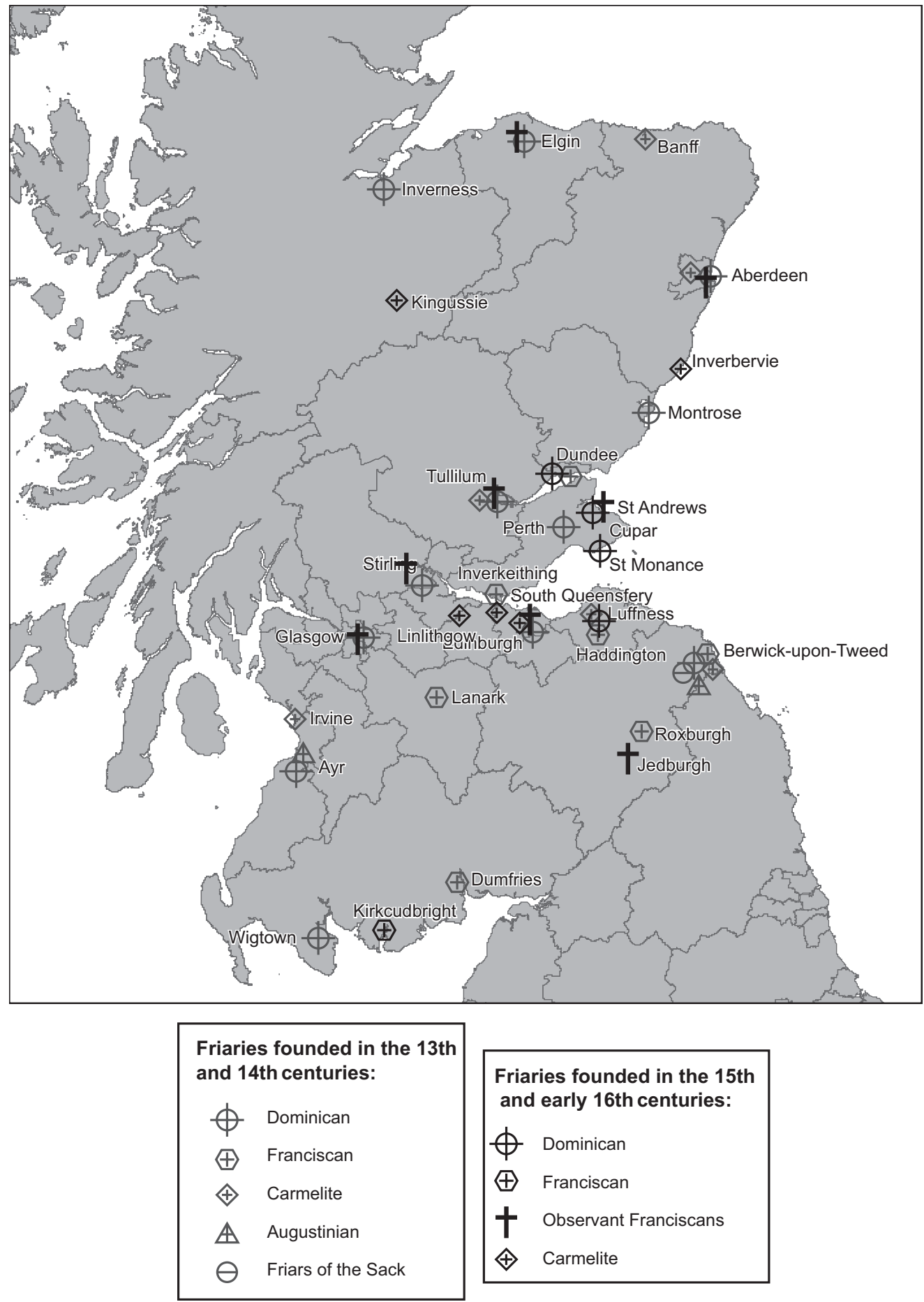

2. I 3 Map showing the location of medieval friaries in Scotland (c I230-I560). After McNeill and MacQueen 1996 (C) Sarah Lambert-Gates 
debate has focused on the question of the culdees and their possible continuity up to the end of the thirteenth century. They are key players in historical discourses that focus on the dualistic opposition between Celtic and Norman, stressing narratives of fierce Celtic resistance and pervasive Norman domination (Hammond 2006). Kenneth Veitch argued that continuity of settlement resulted in important aspects of religious and social continuity (Veitch I999), while Geoffrey Barrow presented evidence for the institutional survival of the culdee at St Andrews for 200 years after the foundation of the Augustinian cathedral priory (Barrow 1973). What can we learn of the process of transition and the hybrid practices that developed at the sites of former culdees? A charter of David I confirms that the intention was to suppress the culdee at St Andrews and transfer its assets to the use of the new canons. Instead, it seems that the bishops converted the old culdee into a secular college of priests that was independent of the Augustinian priory and loyal to the bishop. For a time, two chapters existed at the cathedral of St Andrews, perhaps reflecting the internal political tensions that frequently arose between priors and bishops at cathedral priories. Barrow cites comparable situations at Canterbury and Dublin towards the end of the twelfth century and the beginning of the thirteenth century (Barrow I973: 212-32).

Insight to the lifestyle of the converted culdees is provided by an episode documented at Monymusk in the early thirteenth century. The charter of the Augustinian priory established by Earl Gille Críst of Mar c. I20o confirms that the monastery was established 'in the church of St Mary in which Céle Dé formerly were' (Veitch I999: I2). A dispute quickly arose between the culdee community and the bishop of St Andrews. Pope Innocent III authorised the abbots of Melrose and Dryburgh to investigate the situation and to broker an agreement between the warring parties. The outcome was that the bishop would protect the rights of the culdee if they followed certain stipulations. The community was not to exceed twelve brethren and a prior and they were expressly forbidden to adopt 'the life or order of monks and regular canons'. They 'should have only one refectory and one dormitory in common, and one oratory without cemetery, and that the bodies of the Céle Dé and of clerks and laymen who might die with them should receive the rights of sepulture at the parish church at Monymusk' (Veitch I999: I4). This document confirms that the culdee at Monymusk was allowed to continue its independent existence at least for a generation, with continuity of personnel. It also records that the culdee had adopted a Marian dedication, in common with other communities such as Inchaffray, although it is not clear whether this allegiance was imposed or adopted, for either pious or political motives (Hammond 20IO: 8I). The Monymusk account reveals two further points that are important in understanding the transition to a community of reformed canons. The bishop insisted that the Céle Dé should live a communal lifestyle, following the model 
of coenobitic monasticism and sharing a single dormitory, refectory and oratory. He also withdrew the culdees' privilege to its own cemetery, a right that presumably would have been restored when the old community had faded away and conversion to the Augustinian priory was complete.

There is archaeological evidence relating to the transformation of some of the culdees; for example the round towers at Brechin (Angus) and Abernethy (Perth and Kinross) may belong to the period of their reform, rather than dating to earlier monastic occupation. Eric Fernie argued that they show the influence of Norman architectural style and date to c.IIoo or later (Fernie I986). They follow the Irish model of round towers that were current from the eighth to the twelfth century and may have been chosen to signal a nostalgic connection to the Celtic monastic tradition. However, archaeological analysis suggests that earlier fabric was incorporated in these structures and that their origins may be pre-Norman (Semple 2009). Excavations at Inchaffray provide insight to the colonisation of the former culdee by the Augustinian canons, c. I200, supported by the Earl and Countess of Strathearn. A major programme of landscaping was undertaken on the site of an existing church and community of brethren. Soon after I200, the site was terraced to prepare for the construction of the new church and cloister. These were built over the remains of a $3 \mathrm{~m}$ wide earth bank, perhaps part of the enclosure of the earlier monastery. Temporary structures were identified in the southern part of the site: an early kitchen and oven were found beneath the later west range (Ewart I996).

The process of colonisation is well-documented at Jedburgh, established jointly by David I and Bishop John of Glasgow. Excavations have shown that completion of the full monastic complex may have taken I20 years - four generations of the new community. It is possible that the Anglian minster remained in place while these works were underway, located to the north of the new monastic complex. The church of the Augustinian priory was constructed in stone, beginning in the customary manner at the eastern end. During building works, the canons were accommodated in a series of temporary timber structures located beneath the site of the west range of the cloister (Lewis and Ewart I995: 3, I9-25). At both Inchaffray and Jedburgh, temporary monastic structures were located in the area that would become the west claustral range and which was typically the last monastic range to be constructed.

Excavations at the Isle of May have documented the process of converting the ancient Celtic shrine into a Benedictine cell of Reading Abbey from around II45 (Figure 2.I4). The monks colonised a site with a religious tradition stretching back at least 500 years, based around an existing stone church that was perhaps I5O years old. This church remained in use until a new one was built in the early thirteenth century. A cloister was constructed with 


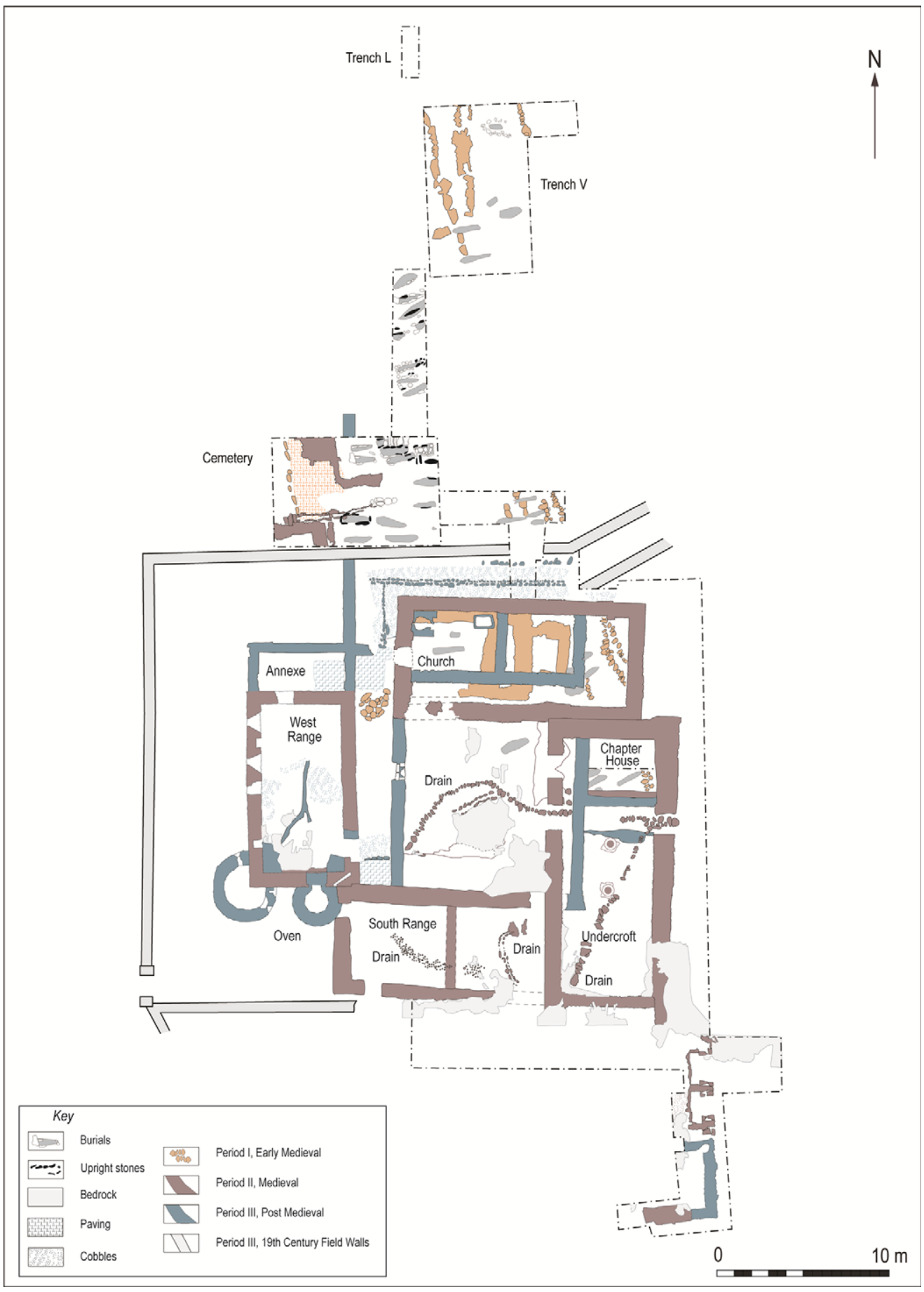

2. I 4 Plan showing excavated area of St Ethernan's Monastery, Isle of May (Fife). Reproduced by kind permission of Tayside and Fife Archaeological Committee 


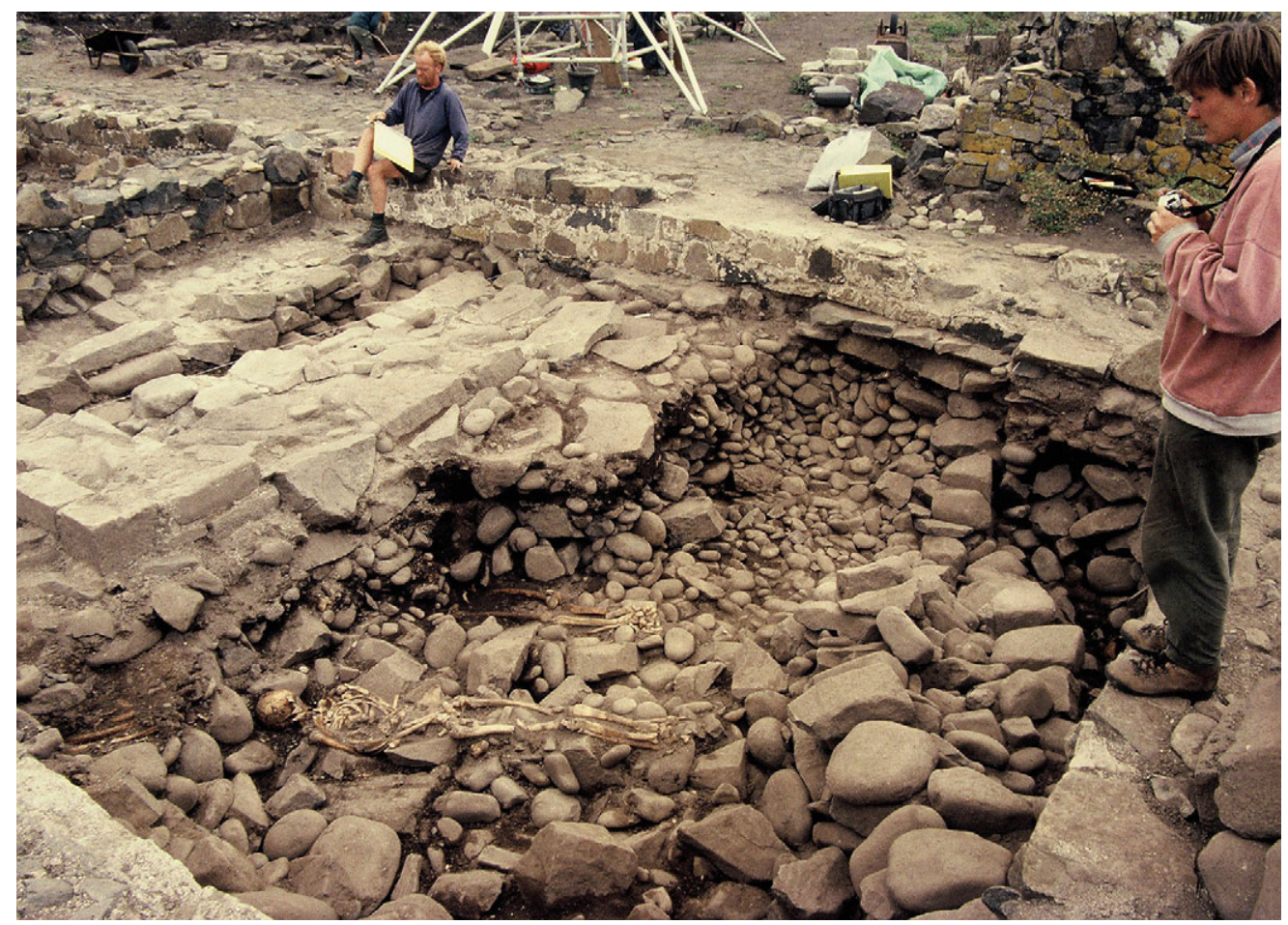

2. I5 Excavation of burials within the cemetery platform at St Ethernan's Monastery, Isle of May (Fife). Photograph by Peter Yeoman (C Fife Council Archaeology Service

the church as the north range; local dolerite stone was quarried for wall cores and dressed sandstone was brought from the mainland for the facings of windows and doors. Four different levels were engineered to create a cloister on this severely constricted site: the church, east range and cloister were on the lowest level; with a step up to the cloister walk and west range; another step up to the south range; and a fourth up to the latrine block (James and Yeoman 2008: 4I). The effort required for construction at May demonstrates the importance of providing a formal cloister, even for a small cell of nine monks. The difficulty of living on the island may explain the early abandonment of the monastery in the thirteenth century, although it remained a popular place of pilgrimage for centuries.

The excavations at May also demonstrated continuity in the unusual burial practices of the island, which continued during and after monastic occupation. A burial ground to the north of the church contained layers of burials separated by beach stones in the manner of a cairn (Figure 2.15). This prompted one of the excavators, Peter Yeoman, to ask: 'why bury a Christian population under a burial cairn, a pagan form of burial, when there were other areas nearby where graves could be dug?' (Yeoman I995: 27). At May, continuity with the early healing shrine was expressed by maintaining ancient burial traditions, 
despite their divergence from the orthodox mortuary traditions of reformed monasticism. At Iona, medieval burials were found crammed into the sandy rock crevices of the shoreline to the south of the abbey, some within roughly formed 'long cists'. The burials were principally of women and two radiocarbon dates suggest that the practice extended from the mid-first millennium up to at least the early second millennium CE (O'Sullivan I999: 229). The control of burial rites and practices would have been an important factor in the religious transition of the twelfth century and is worthy of further study.

The extensive excavations at Whithorn provide insight to the conversion of the Northumbrian minster to a Premonstratensian cathedral priory from around II77, associated with Fergus of Galloway (d. II6I). The archaeology of Whithorn has been characterised as 'urban' from an early date, with evidence of manufacturing, well-defined street systems, coinage and density of occupation (Hill I997: 24-5). However, many of these traits can also be defined as characteristic of early monastic sites, such as the craft-working and manufacturing at Portmahomack and the system of streets and paths at Iona (Carver et al. 20I6; Yeoman I999: 82). The monastery at Whithorn, associated with the cult of St Ninian, became a Northumbrian minster in the eighth century and was destroyed by fire in the ninth century. Peter Hill's interpretation of the archaeological evidence emphasised shifts in the ethnic allegiances of Whithorn as the political and religious landscape changed over time, evolving from Irish to Hiberno-Norse, to Anglian, and demonstrating a 'Gaelic horizon' during the period of the monastic reform of the twelfth century (Hill I997: 56). He used artefacts and building types as indicators of ethnicity; however, caution should be employed in using archaeology as a simple material correlate for ethnicity. It is likely that material culture was exchanged and adapted between social groups and that the religious and commercial communities at Whithorn were socially diverse throughout the ninth to thirteenth centuries.

Archaeological evidence suggests continuity of religious settlement at Whithorn during the largely undocumented period of the ninth to the early eleventh centuries, including the erection of a new timber church on a stone plinth. This provides an institutional context for the sculptured crosses of the Whithorn School. Some of the timber buildings of this phase incorporated hearths, pits and paving, and those in the northern sector produced finds including spindle whorls, ornaments and personal items (Hill I997: 49). Medieval cultural imagery connected spinning with women and spindle whorls are one of the few artefacts that might be regarded as gender-specific at this date (Gilchrist 20I2: I3I, I46). However, spinning may not have been an exclusively feminine task: there is later medieval evidence for men spinning and spindle whorls are routinely excavated from later medieval monastic sites (Standley 2016: 289; Egan 1997). The spindle whorls from Whithorn may indicate that 
women resided at the minster in the tenth or eleventh century, consistent with the model of married clergy staffing the church. Archaeological evidence confirms major expansion at Whithorn in the eleventh to thirteenth centuries, when low-lying areas surrounding the minster were drained and new buildings were erected on reclaimed ground. Whithorn retained its curvilinear plan, with the early monastic precinct forming the central inner precinct and radial paths leading to an outer zone (Hill 1997: 55). Hill concludes that the most unexpected finding for this period is the lack of any clear evidence for the impact of the establishment of the reformed Premonstratensian cathedral priory, arguing that Whithorn remained ostensibly a commercial settlement (a 'monastic town'). However, some indications of significant change can be seen in association with the conversion of the minster to a reformed monastery.

A new church built in the mid-twelfth century seems to have been a simple cruciform with a short nave and long eastern arm. Ralegh Radford noted similarities between Whithorn's plan and the churches of converted culdees at St Andrews (St Mary of the Rock) and the Welsh site of Penmon (Anglesey) (Radford I957: I84). The disproportionately long eastern arm was required for the stalls of the canons' choir. The location of the church at Whithorn is believed to coincide with the alleged site of St Ninian's tomb and perhaps replaced an earlier building (Hill I997: 20, 56), much like the sequence at Iona. A further parallel between Whithorn and Iona is that both communities were provided with a cloister to the north of the church, an adaptation of the standard claustral plan perhaps necessitated by the reuse of the site of the earlier church. Whithorn's church was expanded considerably by the Premonstratensians after $c$.I200, with the nave and choir lengthened and crypts provided for veneration of the relics of St Ninian (Lowe 2009). Architectural fragments suggest that the church and cloister were complete by the mid-thirteenth century (Radford I957: I86).

Artefacts from the inner precinct at Whithorn include writing implements (styli and parchment prickers) that may signal a new emphasis on literacy in the reformed community. Specialist workshops in the outer zone of the monastery were dedicated to comb production and smithing; these outer areas were depopulated by the end of the thirteenth century. This clearance may have been connected with the establishment of a more formal monastic precinct for the Premonstratensian cathedral priory, which is likely to have involved the large-scale relocation of people. Hill argued for social, economic and religious continuity between the minster and the reformed cathedral priory, proposing that the native clergy staffed the new cathedral priory (Hill I997: 23-4, 56, 6I). However, it is doubtful that the strict Premonstratensians would have tolerated married clergy or the presence of women in the monastic precinct. Some significant changes can be seen in the layout and zoning that reflect this 
transition but there was no wholesale redevelopment of the site. We know that the new Whithorn community remained ethnically diverse: in I235, two generations after the Premonstratensian foundation, nearly half of the canons had Gaelic names, including the prior Duncan (Donnchad) (Stringer 2000: I53).

\section{CONCLUSIONS: LATER MEDIEVAL MONASTICISM IN \\ SCOTLAND - 'INVENTIVE, CREATIVE AND REGIONAL'}

A critical, comparative framework of analysis assists in drawing out the distinctiveness of later medieval monasticism in Scotland, exploring how the model of reformed monasticism was 'Scotticised' in the twelfth century. The transition of the culdees seems to have been achieved gradually, involving flexibility and variation in local responses, to match the institutional diversity of early monasticism in Scotland. The archaeological evidence at Whithorn mirrors the historical evidence at St Andrews, indicating gradual change and assimilation rather than abrupt suppression. Excavations have shown that the conversion of Inchaffray, Jedburgh and May all involved rapid campaigns to construct cloisters, requiring terracing and engineering solutions to accommodate the claustral plan on challenging sites. The cloister was regarded as the material cultural signature of reformed monasticism, signalling Scotland's adoption of coenobitic monasticism on the Benedictine model and its rejection of eremitic monasticism rooted in Celtic sacred heritage. The early attention given to building formal cloisters reflects the financial investment that accompanied monastic foundation and perhaps confirms the impression of a peaceful transition to reformed monasticism in Scotland. It also demonstrates the importance of the cloister as an architectural space that structured the embodied experience of monasticism, together with the adoption of literacy as a monastic technology. For instance, the material culture of literacy is prominent in the thirteenth-century conversion of Whithorn and at the nunnery of Elcho. Archaeological evidence from Scottish nunneries confirms that claustral living and literacy were formative techniques of the female monastic body as well as the male. This contrasts with the female monastic experience in later medieval Ireland, where the masonry cloister was not considered to be an essential element of nunnery planning. Accommodation was sometimes provided in detached buildings or timber complexes, and where cloisters were provided, their irregular layout may suggest a more organic development (Collins 2018).

The model of coenobitic monasticism based around claustral living seems to have been fundamental to the conversion of the Scottish culdees. The cloister was also adopted in Ireland around the mid-twelfth century, replacing the concentric enclosures that had characterised Irish monasticism from the fifth 
century up to the reformed monasticism of the twelfth century (O'Keefe 2003: I04). The Welsh experience may have been different: in northwest Wales, eremitic sites were selected for the foundation of Augustinian priories in the thirteenth century at the sites of former Welsh culdees, such as Bardsey (Gwynedd), Beddgelert (Gwynedd), Penmon (Anglesey), Ynys Lannog (Puffin Island, Anglesey) and Ynys Tudwall (Gwynedd). Excavations at Tudwall revealed a cluster of simple buildings associated with a small church in a stone enclosure. Karen Stöber and David Austin argue that the first phase of Augustinian foundations at the Welsh culdees 'used the native motif of building clusters within enclosures' (Stöber and Austin 2013: 46). Traditional elements were also retained in the conversion of the Scottish culdees, for example the Irish-inspired round towers at Brechin and Abernethy, and the burial cairns at May. But the most significant indicator of continuity was the choice of location for the church: at traditional cult sites like Whithorn and Iona it was essential that the saint's grave and shrine were integrated within the rebuilding of the church, as it was at Irish monasteries such as Clonmacnoise (co Offaly) and Inishmurray (co Sligo). Direct continuity of place was also critical in establishing new monasteries at former minsters, such as Jedburgh, and culdees including Inchaffray and May.

The distinctiveness of Scottish monasticism can be found in the hybrid practices that connected reformed monasticism with Celtic sacred heritage. The time is ripe for archaeologists to critically reassess the significance of the perceived watershed of $c$. IIOO, just as historians are reflecting on the conventional framework of periodisation and its impact on historical scholarship (Hammond 2006; see Campbell 2013b for a material culture perspective). In 'understanding why, where and how' Scotland emerged (ScARF 20I2: i), we must explore the longer transition of Scottish religious experience from the tenth to the thirteenth century. Documentation for religious communities in Scotland is exceedingly rare in the tenth and eleventh century (Hammond 2010: 62), increasing the value of an archaeological perspective. Recent excavations in Aberdeen suggest that monasteries were sometimes founded on early cemeteries that are undocumented: skeletons dating to the tenth or eleventh century have been excavated at the site of Aberdeen's Dominican Friary, founded 200 years later by Alexander II (c.1230-49) (Cameron 20I6). To what extent did the new monasteries incorporate elements of Celtic monasticism that had borrowed from the prehistoric tradition? Carver (2009) suggested that the early Christian tradition in Scotland integrated prehistoric practices such as the use of curvilinear enclosures, stone slab cist burials, stone markers and the curation of ancestral bones. These elements continued in the reformed monasticism of the twelfth century, with the important exception of curvilinear enclosures, which were replaced emphatically by cloisters. 
It is also imperative to develop more critical perspectives around ethnicity in twelfth-century Scotland: how were Gaelic, Scandinavian and Anglo-Norman traditions expressed and renegotiated through monastic material culture? Here, we could learn from medieval archaeologists who have explored diaspora identities such as the Hansa, the German merchants who settled in Baltic Europe, or the Normans in Anglo-Saxon England (e.g. Gaimster 20I4; Naum 20I5; Sykes 2005). These approaches have emphasised the potential of ceramic material culture and food remains in exploring cultural signatures connected with ethnic identity. A key source for exploring this theme in Scottish monastic archaeology is burial evidence (see Chapter 4). The Scottish case study demonstrates the value of comparative and critical assessments of regional monastic archaeology. By evaluating Scotland in the wider context of European monasticism, it also contributes to the development of an international research agenda for Scottish historical archaeology (Dalglish and Driscoll 20I0: 3I4). A critical framework of archaeological analysis helps us to appreciate the value and significance of Scottish medieval monasticism - just like its Celtic precursor, later medieval monastic experience in Scotland was richly 'inventive, creative and regional'. 